\title{
Extended Characterisation of Five Archival Tick- borne Viruses Provides Insights for Virus Discovery in Australian Ticks
}

\section{Caitlin A. O’Brien}

University of Queensland - Saint Lucia Campus: The University of Queensland

\section{Bixing Huang}

Queensland Health Scientific Services: Health Support Queensland Forensic and Scientific Services

\section{David Warrilow}

Queensland Health Scientific Services: Health Support Queensland Forensic and Scientific Services

\section{Jessamine E. Hazlewood}

Queensland Institute of Medical Research - QIMR: QIMR Berghofer Medical Research Institute

\section{Helle Bielefeldt-Ohmann}

University of Queensland - Saint Lucia Campus: The University of Queensland

\section{Sonja Hall-Mendelin}

Queensland Health Scientific Services: Health Support Queensland Forensic and Scientific Services

\section{Cassandra L. Pegg}

University of Queensland - Saint Lucia Campus: The University of Queensland

Jessica J. Harrison

University of Queensland - Saint Lucia Campus: The University of Queensland

\section{Devina Paramitha}

University of Queensland - Saint Lucia Campus: The University of Queensland

Natalee D. Newton

University of Queensland - Saint Lucia Campus: The University of Queensland

Benjamin L. Schulz

University of Queensland - Saint Lucia Campus: The University of Queensland

Andreas Suhrbier

Queensland Institute of Medical Research - QIMR: QIMR Berghofer Medical Research Institute

Jody Hobson-Peters

University of Queensland - Saint Lucia Campus: The University of Queensland

Roy Alexander Hall ( $\nabla$ roy.hall@uq.edu.au )

University of Queensland 
Keywords: Ixodes holocyclus, Ixodes uriae, tick-borne flavivirus, tick-borne orbivirus, Nairoviridae, tickborne phlebovirus, virus discovery

Posted Date: October 19th, 2021

DOI: https://doi.org/10.21203/rs.3.rs-981794/v1

License: (c) (1) This work is licensed under a Creative Commons Attribution 4.0 International License. Read Full License

Version of Record: A version of this preprint was published at Parasites \& Vectors on February 18th, 2022. See the published version at https://doi.org/10.1186/s13071-022-05176-z. 


\section{Abstract}

\section{Background}

A subset of Australians who have been bitten by ticks experience a complex of chronic and debilitating symptoms which cannot be attributed to the known pathogenic species of bacteria present in Australia. As a result, there has been a renewed effort to identify and characterise viruses in Australian terrestrial ticks. Recent transcriptome sequencing of Ixodes and Amblyomma ticks have revealed the presence of multiple virus sequences. However, without virus isolates our ability to understand the host-range and pathogenesis of newly identified viruses is limited. We have established a successful method for highthroughput virus discovery and isolation in mosquitoes using antibodies to double-stranded RNA. In this study we sought to characterise five archival tick-borne viruses in order to adapt our virus discovery protocol for Australian ticks.

\section{Methods}

We performed virus characterisation using a combination of bioinformatic sequence analysis and in vitro techniques including replication kinetics, antigenic profiling, virus purification and mass spectrometry.

Results

Our sequence analysis of three archival viruses revealed marked genetic stability in isolates collected from the same location approximately 30 years apart. We demonstrate that the Ixodes scapularis-derived ISE6 cell line supports replication of Australian members of the Flaviviridae, Nairoviridae, Phenuiviridae and Reoviridae families, including a virus isolated from the soft tick Ornithodoros capensis. While antibodies against double-stranded RNA could be used to detect replication of a tick-borne reovirus and mosquito-borne flavivirus, the tick-borne flaviviruses Gadgets Gully virus and Saumarez Reef virus could not be detected using this method. Finally, four novel virus-like sequences were identified in transcriptome sequencing of the Australian native tick Ixodes holocyclus.

\section{Conclusions}

Genetic and antigenic characterisation of archival viruses in this study confirm that three viruses described in 2002 represent contemporary isolates of virus species first identified 30 years prior. Our findings with antibodies to double-stranded RNA highlight an unusual characteristic shared by two Australian tick-borne flaviviruses. Overall, this work provides a valuable resource for isolation of Australian tick-borne viruses using existing cell lines.

\section{Background}

While Australia is home to a range of mosquito-borne viral pathogens (1), at present there are no recognised tick-borne viral diseases (2). This is at odds with the rest of the world where tick-borne viruses pose significant threats to both human and animal health (3-7). Despite this, a subset of Australians live 
with a chronic, incapacitating syndrome now termed "Debilitating Symptom Complexes Attributed to Ticks" (DSCATT) which cannot be explained by the known tick-borne bacterial pathogens found in Australia (2). With the recognition of DSCATT, a focus of research has moved towards identifying potential emerging pathogens in Australian terrestrial ticks.

Australia is home to at least 70 species of ticks, many of which are unique to the continent (8). However, migratory birds also carry ticks which are found elsewhere in the world including Ixodes uriae, Argas robertsi and Ornithodoros capensis. The search for tick-borne viruses in Australia was first initiated in the 1970s by the Commonwealth Science and Industrial Research Organisation (CSIRO). This work yielded isolates belonging to at least 5 different viral families (Nairoviridae, Phenuiviridae, Flaviviridae, Reoviridae, Orthomyxoviridae), primarily from seabird-associated ticks (Fig. 1). Macquarie Island is a subAntarctic island located halfway between Tasmania, Australia and Antarctica. The island is home to large rookeries of penguins and the ticks that infest them, including the hard tick $I$. uriae. Collections of $I$. uriae from the island between 1972 and 1979 led to the isolation of Gadgets Gully virus (GGYV, Flaviviridae); Precarious Point virus (PPV, Phenuiviridae), Taggert virus (TAGV, Nairoviridae) and Nugget virus (NUGV, Reoviridae) $(9,10)$. In addition, Saumarez Reef virus (SREV, Flaviviridae) was isolated from seabirdassociated ticks collected on Saumarez Reef off the coast of Queensland (QLD; O. capensis) and Tasmania (I. eudyptidis) in 1974 (Fig. 1) (11). Serology-based analyses showed each of these viruses shared antigenic relatedness to tick-borne viruses of the Northern Hemisphere, some of which include human pathogens such as Kemerovo virus and tick-borne encephalitis virus (9-11). PPV, TAGV, GGYV and SREV have since been sequenced, further supporting these links with the Northern hemisphere (1214).

A re-survey of I. uriae ticks from Macquarie Island in 2002 resulted in the re-isolation of GGYV (15), approximately 30 years after its initial isolation (10). Despite the length of time between collections, sequencing of the E and NS1 genes showed minimal genetic variation between these isolates. This study also yielded three additional arbovirus isolates, Sandy Bay virus (SBaV, Reoviridae), Finch Creek virus (FCV, Nairoviridae), and Catch-me-cave virus (CMCV, Phenuiviridae), for which partial genome sequence was obtained (Fig. 1) (15). A comparison of the S segment of CMCV and PPV indicated that the two viruses were closely related; however, the $L$ and $M$ segment of $C M C V$ could not be obtained. At the time of this study no genomic information was available for TAGV; however, in 2016 sequencing of this virus showed it to be very similar to the available sequence of FCV, specifically, a $392 \mathrm{nt}$ region of the $\mathrm{L}$ segment (14).

To our knowledge the only viruses to be isolated from ticks on the Australia mainland are Lake Clarendon virus, Vinegar Hill virus (VINHV) and a strain of Kao Shuan virus all of which were derived from the soft tick $A$. robertsi (Fig. 1) (16-18). Little is known about the pathogenicity of these archival viruses, although antibodies to VINHV and GGYV have been identified in human sera with no known reports of illness in the serum donors $(17,19)$. Mostly, these viruses are not deemed to pose an imminent risk to public health or agriculture, or they are isolated from regions not populated by humans. As a result, for many of these isolates little characterisation has been undertaken since the initial reports. 
Recent meta-transcriptomic survey of ticks from New South Wales (NSW), Australia, have identified a number of novel virus sequences including Shelly Headland virus, which groups with the human pathogens Colorado tick fever virus and Eyach virus $(20,21)$. While next generation sequencing technologies are an invaluable asset in the field of virus discovery, isolation of viruses of interest are necessary to further our understanding of host-range and pathogenesis for potential emerging viruses (22).

We have developed a novel system for broad-spectrum identification of RNA viruses based on the detection of double-stranded RNA (dsRNA) (23). The MAVRIC (monoclonal antibodies to viral RNA intermediates in cells) system identifies cultures positive for virus replication in a sequence-independent manner. Based on the successful implementation of this system for virus discovery in Australian mosquitoes (24-29), we assessed the utility of the MAVRIC system for virus discovery in Australian tick populations. Traditionally, arbovirus isolation has been performed on vertebrate cell lines, with Vero and BHK cells commonly used. However, even these cell lines can show varying levels of permissiveness to different viruses $(26,30)$. The I. scapularis-derived ISE6 cell line is well-established from this tick species which is found in eastern USA and Canada. This cell line, has been shown to support replication of a number of tick-borne viruses as well as the mosquito-borne flavivirus West Nile virus New York 99 strain (31-33). However, the permissiveness of this cell line for isolation of viruses from native Australian ticks is unclear (34).

In this study we assessed the potential for the use of the MAVRIC system for discovery of and isolation of Australian tick viruses. Using a panel of Australian archival tick viruses, we sought to further characterise the replication of these viruses and the utility of MAVRIC for Australian tick virus discovery.

\section{Methods}

\section{Tick cell culture}

ISE6 (I. scapularis) cells were maintained in complete ISE6 cell medium containing L-15B300 media supplemented with $0.1 \%$ LipiMAX bovine lipoprotein solution (Selbourne Biological, Tasmania, Australia), 10\% tryptose phosphate broth (Oxoid - Thermo Fisher, Basingstoke, UK) and $5 \%$ fetal bovine serum (FBS, Bovogen, Victoria, AUS). L-15B300 media was made in house using triple-autoclaved ultrapure water, Leibovitz-15 (L-15) media (Lonza, Gibco) and trace minerals as per (35). The details for each reagent are described in Additional file 1: Table S1. Cells were frozen in complete medium containing $15 \% \mathrm{FBS}$ and $10 \%$ DMSO using the CoolCell LX cell freezing container (Corning). Cells were revived in a T25 non-vented flask and maintained by replacing media every $7-10$ days, for one month before upscaling to a T75 non-vented flask. Upscaled cells were maintained for a minimum of one month before seeding for experiments. Cells were maintained at $34^{\circ} \mathrm{C}$ without $\mathrm{CO}_{2}$.

\section{Vertebrate and mosquito cell culture}


Vero (Chlorocebus Monkey kidney cells), BHK (baby hamster kidney cells, Mesocricetus auratus) and BSR (clone of baby hamster kidney cell line, Mesocricetus auratus) cells were maintained in Dulbecco's Modified Essential Medium (DMEM) supplemented with 5\% FBS. Opossum (Didelphidae) kidney (OK) cells were maintained in Roswell Park Memorial Institute (RPMI) medium supplemented with $5 \%$ FBS. All vertebrate cells were maintained at $37^{\circ} \mathrm{C}$ in the presence of $5 \% \mathrm{CO}_{2} . \mathrm{C} 6 / 36$ cells (Aedes albopictus, mosquito larvae-derived) were cultured in RPMI supplemented with $5 \% \mathrm{FBS}$ and grown at $28^{\circ} \mathrm{C}$ without $\mathrm{CO}_{2}$.

\section{Production of stocks of archival viruses}

Virus stocks were prepared by inoculation of vertebrate or $\mathrm{C} 6 / 36$ cells as per Table 1 at approximately $80 \%$ confluency. Where titres were known, inoculation was performed at a multiplicity of infection (MOI) of 0.1 . Where virus titres in the inoculum were unknown, $100 \mu \mathrm{L}$ of inoculum was used. After an adsorption period of 1 hour at room temperature with agitation, virus inoculum was removed and replaced by DMEM (or RPMI for C6/36 cells) supplemented with $2 \% \mathrm{FBS}$. Cells were incubated at $37^{\circ} \mathrm{C}$ for 2 to 7 days. Supernatant was harvested and clarified by centrifugation at $3000 \mathrm{rpm}$ for 15 minutes at $4^{\circ} \mathrm{C}$. FBS content in culture supernatant was raised to $10 \%$ prior to aliquoting and storage at $-80^{\circ} \mathrm{C}$.

Table 1

Virus stocks used in this study

\begin{tabular}{|c|c|c|c|c|c|}
\hline Virus (reference) & Abbreviation & Strain & $\begin{array}{l}\text { Tick } \\
\text { species }\end{array}$ & $\begin{array}{l}\text { Cell line (no. } \\
\text { days) }\end{array}$ & $\begin{array}{l}\text { Passage history (cel } \\
\text { line) }\end{array}$ \\
\hline $\begin{array}{l}\text { Gadgets Gully } \\
\text { (10) }\end{array}$ & GGYV & $\begin{array}{l}\text { CSIRO } \\
122\end{array}$ & 1. uriae & BSR (5) & $x^{a}+2(B H K, B S R)$ \\
\hline $\begin{array}{l}\text { Saumarez Reef } \\
\text { (11) }\end{array}$ & SREV & CSIRO 4 & $\begin{array}{l}\text { O. } \\
\text { capensis }\end{array}$ & BHK (3) & $\mathrm{X}+2(\mathrm{BHK})$ \\
\hline West Nile (51) & $W_{N} V_{\text {KUN }}$ & NSW2011 & Mosquito & $\mathrm{BHK}(2)$ & $\mathrm{X}+1(\mathrm{BHK})$ \\
\hline West Nile (70) & $W N V_{K U N}$ & MRM61C & Mosquito & $\mathrm{C} 6 / 36(5)$ & $X+1$ (Vero) \\
\hline Finch Creek (15) & FCV & EB06 & I. uriae & Vero (6) & 6 (Vero) \\
\hline Taggert (9) & TAGV & MI14850 & I. uriae & Vero (7) & $\mathrm{X}+1$ (BSR) \\
\hline $\begin{array}{l}\text { Catch-me-cave } \\
\text { (15) }\end{array}$ & CMCV & $\mathrm{I}-2$ & I. uriae & Vero (5) & $x+2$ (Vero) \\
\hline Nugget (9) & NUGV & MI14847 & I. uriae & $\operatorname{BSR}(7)$ & $\mathrm{X}+1$ (BSR) \\
\hline
\end{tabular}

All viruses were titrated onto BSR and Vero cells and titres were determined by $\mathrm{TCID}_{50}$ using the ReedMuench method (36). Virus replication was determined by fixed-cell ELISA using the pan-flavivirus mAb 4G2 for SREV and GGYV, MAVRIC for NUGV and anti-FCV mouse immune serum for FCV and TAGV. Replication of CMCV was determined by the presence or absence of cytopathic effect (CPE). 


\section{Tick homogenisation and passaging}

Adult I. holocyclus ticks collected in Lismore, which had been blood fed on rats for an unrelated experiment, were stored at $-80^{\circ} \mathrm{C}$. Pools of 5 ticks were thawed on ice and added to $5 \mathrm{~mL}$ microcentrifuge tubes with $4 \mathrm{~mL}$ of chilled complete ISE6 media. Homogenisation was performed with a $5 \mathrm{~mm}$ stainless steel bead for two minutes, followed by centrifugation at $3000 \mathrm{rpm}$ for 15 minutes at $4^{\circ} \mathrm{C}$ to pellet debris. Clarified supernatant was passed through a $0.2 \mu \mathrm{m}$ filter. Filter-sterilised supernatant was used immediately to inoculate cells and thereafter stored at $-80^{\circ} \mathrm{C}$. Inoculum was removed from vertebrate cells after 2 hours and replaced with appropriate maintenance media before cells were incubated at $37^{\circ} \mathrm{C}$ with $5 \% \mathrm{CO}_{2}$ for 5 days post-infection (dpi). Inoculum was left on ISE6 cells for $7-9 \mathrm{dpi}$ at $34^{\circ} \mathrm{C}$ without $\mathrm{CO}_{2}$.

\section{RNA extraction and RT-PCR}

RNA extraction was performed on homogenates and cell culture supernatant using the Machery Nagel Viral RNA isolation kit as per manufacturers' instructions. RT-PCR testing was performed using the SuperScript ${ }^{\text {TM }}$ III One-Step RT-PCR System with Platinum ${ }^{\text {TM }}$ Taq DNA Polymerase (Invitrogen) and primer sets listed in Table 1. Cycling conditions for each PCR is as follows; reverse transcription: $45^{\circ} \mathrm{C}$ for 30 min; PCR: one cycle $94^{\circ} \mathrm{C}$ for 2 min; 40 cycles $94^{\circ} \mathrm{C}$ for $30 \mathrm{~s}$, (annealing temperature listed in Table 2) for $30 \mathrm{~s}, 68^{\circ} \mathrm{C}$ for $1 \mathrm{~min}$; followed by a final extension cycle of $68^{\circ} \mathrm{C}$ for $5 \mathrm{~min}$.

Table 2

Primer sets used in this study

\begin{tabular}{|c|c|c|c|}
\hline Primer name & Sequence $\left(5^{\prime}-3^{\prime}\right)$ & Product size (bp) & Annealing temperature $\left({ }^{\circ} \mathrm{C}\right)$ \\
\hline PVL1 Forward & TCACACCTTGGGCATTCTCC & \multirow[t]{2}{*}{679} & \multirow[t]{2}{*}{51} \\
\hline PVL1 Reverse & AAACCGAGACACCATCACCC & & \\
\hline PVL2 Forward & CTACTGACATGCGAGTTCC & \multirow[t]{2}{*}{185} & \multirow[t]{2}{*}{45} \\
\hline PVL2 Reverse & CAGTCGACGAGACACAACCG & & \\
\hline PVL3 Forward & GATTTTGGTCATGGCAGC & \multirow[t]{2}{*}{435} & \multirow[t]{2}{*}{45} \\
\hline PVL3 Reverse & CACTTGGCATACAGCTGG & & \\
\hline Rhabdo-like F & CCTTAGGCCGACGTCTTATCC & \multirow[t]{2}{*}{263} & \multirow[t]{2}{*}{51} \\
\hline Rhabdo-like R & GAGCAGTTCTTTGGCTTGCC & & \\
\hline
\end{tabular}

\section{MAVRIC ELISA}

BHK cells infected with SREV, GGYV and WNV KUN $_{\text {in }}$ 96-well plates were fixed with $200 \mu \mathrm{L}$ per well $20 \%$ acetone fixative buffer $(20 \% \mathrm{~V} / \mathrm{v}$ acetone, $0.02 \% \mathrm{~W} / \mathrm{v}$ bovine serum albumin in in phosphate buffered saline (PBS, $\left.140 \mathrm{mM} \mathrm{NaCl}, 2.7 \mathrm{mM} \mathrm{KCl}, 6 \mathrm{mM} \mathrm{Na}_{2} \mathrm{HPO}_{4}, 0.9 \mathrm{mM} \mathrm{KH}_{2} \mathrm{PO}_{4}\right)$ ) overnight at $4^{\circ} \mathrm{C}$, or 150 $\mu \mathrm{L} /$ well formaldehyde fixative buffer ( $4 \%$ formaldehyde, $0.5 \% \mathrm{v} / \mathrm{v}$ Triton X-100 in PBS) for 10 minutes at 
$4^{\circ} \mathrm{C}$. After incubation, the fixative was removed, and plates were dried at room temperature for 48 hours before use. BSR, OK and ISE6 cells inoculated with I. holocyclus homogenates were fixed using formaldehyde fixative buffer only.

Plates were pre-blocked with $150 \mu \mathrm{L} /$ well TENTC blocking buffer ( $2 \% w / v$ casein, $0.05 \% v / v$ Tween-20, 10 $\mathrm{mM}$ Tris, $0.2 \mathrm{M} \mathrm{NaCl}, 1 \mathrm{mM}$ EDTA, $\mathrm{pH}$ 8.0) for $1 \mathrm{~h}$ at room temperature. A cocktail of monoclonal antibodies (mAbs) $3 \mathrm{G} 1$ and 2G4 (MAVRIC) was prepared by diluting hybridoma supernatant in TENTC blocking buffer to previously determined optimal concentrations. Blocked plates were incubated with 50 $\mu \mathrm{L} /$ well MAVRIC for 1 hour at $37^{\circ} \mathrm{C}$, followed by four washes with PBS containing $0.05 \% v / v$ Tween-20 (PBS-T). A 1:2000 dilution of secondary goat anti-mouse HRP (DAKO) in TENTC blocking buffer (50 $\mu \mathrm{L} /$ well) was then added, followed by another incubation for 1 hour at $37^{\circ} \mathrm{C}$. Plates were washed six times with PBS-T and developed using $100 \mu \mathrm{L} /$ well of substrate buffer (1 mM 2,2*-Azino-bis(3ethylbenzothiazoline-6-sulfonic acid) (ABTS), $2.5 \mathrm{mM} \mathrm{H}_{2} \mathrm{O}_{2}$, in a solution prepared by mixing $0.1 \mathrm{M}$ citric acid with $0.2 \mathrm{M} \mathrm{Na}_{2} \mathrm{HPO}_{4}$ to give a pH of 4.2 ) for $1 \mathrm{~h}$ at room temperature, protected from light. Absorbance was measured at $405 \mathrm{~nm}$ and samples with an average $\mathrm{OD}_{405 \mathrm{~nm}}$ equal to or greater than twice that of the average mock reading were considered positive.

\section{Antigenic analyses}

Antigenic analysis of SREV and GGYV, was performed on BHK cells infected at a $\mathrm{MOI}$ of 0.1 for 48 hours in 96 -well plates and fixed with $20 \%$ acetone fixative buffer as described above. Serial two-fold dilutions of mAbs in TENTC blocking buffer were tested. For mAbs in hybridoma supernatant a starting dilution of neat $(\mathrm{P} 3 \mathrm{H} 8)$ or 1:5 $(4 \mathrm{G} 2,6 \mathrm{~B} 6 \mathrm{C})$ was used, while 1D1 (purified mAb) and M2-1E7 (ascitic fluid) were used at a starting dilution of $1: 500$. Primary antibody was added to plates at $50 \mu \mathrm{L} /$ well and incubated at $37^{\circ} \mathrm{C}$ for 1 hour. Fifty $\mu \mathrm{L}$ of goat anti-mouse HRP (1:2000) was added to plates and incubated for 30 minutes at $37^{\circ} \mathrm{C}$.

Anti-FCV ELISA using mouse immune sera was performed on BSR cells infected with FCV or TAGV at MOI of 0.1 for 5 days and fixed with acetone fixative buffer as described above. Serial dilutions of anti-FCV serum of 1:200 to 1:25600 were prepared in TENTC blocking buffer. Both primary and secondary antibody (goat anti-mouse 1:2000, DAKO) were added to plates at a volume of $50 \mu \mathrm{L} /$ well and incubated for $1 \mathrm{~h}$ at $37^{\circ} \mathrm{C}$.

All plates were pre-blocked, washed and developed as described for the MAVRIC ELISA.

\section{Purification of viruses}

Partial purification was performed on CMCV and FCV. Five T175 flasks per virus were seeded with BSR cells at $80 \%$ confluence one day prior to infection. Cells were infected with CMCV or FCV at a MOI of 0.1 for 1 hour at room temperature with gentle agitation. Inoculum was removed and replaced with $18 \mathrm{~mL} 2 \%$ FBS/DMEM per flask. Cells were incubated for 5 days at $37^{\circ} \mathrm{C}$ before harvesting supernatant and clarifying by centrifugation at $3000 \mathrm{rpm}$ for $15 \mathrm{~min}$ at $4^{\circ} \mathrm{C}$. Two parts clarified supernatant was mixed with 1 part 40\% PEG6000 solution (40\% w/v polyethylene glycol 6000 in PBS) overnight at $4^{\circ} \mathrm{C}$. Virus was 
pelleted by centrifugation at 12,000 rpm for 1 hour at $4^{\circ} \mathrm{C}$ in a JLA16.250 rotor. Precipitated virus was resuspended in cold PBS. As the pathogenicity of CMCV and FCV in mice is unknown, the virus preparations were inactivated in preparation for their use as antigens for immunisation of mice. To do this a solution of binary ethyleneimine (BEI) was prepared by the addition of $3-10 \mathrm{mM} 2-$ bromoethylamine to DMEM brought to $\mathrm{pH} 9.0$ with $2 \mathrm{~N} \mathrm{NaOH}$ and warmed to $37^{\circ} \mathrm{C}$. PEG-precipitated virus was resuspended in the BEI-DMEM solution and incubated at $37^{\circ} \mathrm{C}$ overnight before BEl was neutralised by the addition of sodium thiosulfate to a final concentration of $0.1 \mathrm{M}$. The inactivated virus preparation was then layered onto a cushion of $20 \%$ sucrose in NTE buffer (10 mM Tris, $1 \mathrm{mM}$ EDTA, $120 \mathrm{mM} \mathrm{NaCl}$, $\mathrm{pH}$ 8.0) followed by centrifugation at $28,000 \mathrm{rpm}$ for 2 hours at $4^{\circ} \mathrm{C}$ in a $S W 32$ rotor. Pelleted virus was incubated in PBS at $4^{\circ} \mathrm{C}$ overnight. After pellets were resuspended, the samples underwent three rounds of buffer exchange in $5 \mathrm{~mL}$ PBS using high molecular weight (100K) MWCO Spin-X UF concentrator columns (Corning) before concentrating to a final volume of 100-200 $\mu \mathrm{L}$. Purified virus was stored at $-80^{\circ} \mathrm{C}$ until use.

\section{Protein analysis by SDS-PAGE and western blot}

Purified virus preparations were diluted in $4 \times$ NuPAGE LDS sample buffer (Invitrogen) without boiling or reducing and analysed by SDS-PAGE using a $4-12 \%$ Bis-Tris gel (NuPAGE) at $170 \mathrm{~V}$ for 42 minutes in $1 \mathrm{x}$ Tris-glycine running buffer. Gels were stained using SYPRO Ruby protein stain (Thermo Fisher Scientific) as per manufacturer's instructions and imaged on a UV transilluminator.

FCV or uninfected cell lysate was prepared by harvesting BSR cells from a T75 flask in NP-40 lysis buffer (1\% NP-40 in $150 \mathrm{mM} \mathrm{NaCl}, 50 \mathrm{mM}$ Tris-HCl [pH 7.3], 1:100 protease inhibitor cocktail (P8340, Sigma, St Louis, MO, USA)) for $30 \mathrm{~min}$ at $4^{\circ} \mathrm{C}$. Lysate was clarified by centrifugation at $10,000 \mathrm{~g}$ for $10 \mathrm{~min}$ at $4^{\circ} \mathrm{C}$ and stored at $-80^{\circ} \mathrm{C}$ until use. To test anti-FCV immune sera, electrophoresis of cell lysates was performed as described above and proteins were transferred to a nitrocellulose membrane at $30 \mathrm{~V}$ for 60 minutes. The membrane was pre-blocked with TENTC blocking buffer and probed with anti-FCV serum diluted 1:200 in TENTC blocking buffer. The membrane was washed 3 times with Tris-buffered saline $(20 \mathrm{mM}$ Tris- $\mathrm{HCl} \mathrm{pH} \mathrm{7.5,} \mathrm{NaCl:} 150 \mathrm{mM}, 0.05 \% \mathrm{v} / \mathrm{v}$ Tween-20 detergent) before addition of goat-anti mouse conjugated with IRDye800 (LI-COR) diluted at 1:8000 in blocking buffer for $1 \mathrm{~h}$ at room temperature. The blot was imaged using the Odyssey CLx.

\section{Mass spectrometry}

FCV protein bands which were visible by eye after gel electrophoresis were excised under UV illumination and stored at $-20^{\circ} \mathrm{C}$. Gel slices were destained overnight at $37^{\circ} \mathrm{C}$ in a solution of $50 \%$ acetonitrile/50 mM ammonium acetate. Proteins were reduced with $10 \mathrm{mM}$ dithiothreitol for $1 \mathrm{~h}$ and cysteine residues were alkylated by addition of $25 \mathrm{mM}$ acrylamide and incubated for $1 \mathrm{~h}$ at $23^{\circ} \mathrm{C}$. Gel slices were dried and peptides were digested overnight with $500 \mathrm{ng}$ trypsin in a solution containing $50 \mathrm{mM}$ ammonium acetate solution. Digested peptides were desalted and analysed using liquid chromatography mass spectrometry (LC-MS/MS) as described in (37). Peptides were identified using ProteinPilot Software 5.0.2.0 (SCIEX) and a custom protein database containing Mesocricetus auratus (BSR cell line) proteins and the amino 
acid sequences of FCV RdRP, nucleocapsid and glycoprotein precursor. Standard search settings included: sample type, identification; digestion, trypsin; Cys alkylation, acrylamide; search effort, thorough; ID focus, biological modifications. False discovery rate analysis using ProteinPilot was performed on all searches.

\section{Generation of mouse immune serum to Finch Creek virus}

All animal procedures had received prior approval from The University of Queensland Animal Ethics Committee (AEC \#SCMB/329/15/ARC) and, where necessary, were performed under ketamine:xylazine anaesthesia. BEl-inactivated FCV along with inulin-based adjuvant Advax (Vaxine Ltd., Adelaide, Australia) was used to immunise a 6 week-old BALB/c mouse (Animal Resources Centre, Murdoch, Western Australia, Australia) via the subcutaneous route (s.c.). Mice were kept on clean bedding and given food and water ad libitum. The immunized mouse was bled via the tail vein at two weeks following immunization and the serum tested for evidence of seroconversion to FCV using

a fixed-cell ELISA as described above. A second dose of antigen was delivered 6 weeks after the initial dose. Two weeks after receiving the second dose, the mouse was euthanized by a ketamine:xylazine overdose and blood for serum-procurement was harvested via cardiac puncture.

\section{Sequencing of viruses}

Nugget virus (NUGV, MI14847) RNA was extracted from culture supernatant from an archival virus stock using the QIAamp Viral RNA extraction kit (QIAGEN, Hilden, Germany) with carrier RNA omitted and DNA Wipeout was used to remove residual cell line DNA (Qiagen). First-strand CDNA synthesis was performed with Protoscript II kit using the supplied random primer mix (New England Biolabs; Ipswich, MA, USA). Second-strand DNA synthesis was performed using the NEBNext mRNA Second-Strand Synthesis Module (New England Biolabs). The Nextera XT library kit (Illumina; San Diego, California, USA) was used to construct cDNA libraries with individual samples barcoded. All reactions were performed according to the conditions recommended by the respective manufacturers. Library sequencing was performed by the Australian Genome Research Facility (AGRF) on a HiSeq Illumina sequencer (125 nt paired end reads). Sequence assembly was performed using the de novo assembly tool in Geneious v8 at low sensitivity using $125 \mathrm{bp}$ read lengths.

Preparations of FCV EB06 and CMCV I-2 for sequencing were generated by PEG-precipitation of virus from supernatant of $2 \times T 175$ flasks of BSRs as described above. Sequencing for these viruses was performed as described for NUGV with the following modifications; DNAse-treatment was performed using Heat\&Run DNase (ArcticZymes), second-strand DNA synthesis was performed using Escherichia coli DNA ligase, DNA polymerase I, and ribonuclease $\mathrm{H}$ (New England Biolabs). The resulting libraries were sequenced on a NextSeq 500 generating $2 \times 151$-base pair paired reads. The viral genome was assembled using Geneious R8 software as described above.

\section{Growth kinetics}


ISE6 and BSR cells were seeded in 24-well plates at a density of $10^{5}$ cells per well, 24 hours prior to infection. For NUGV, one replicate from each time point was seeded onto sterile glass coverslips in 24-well plates. On the day of infection, seeding media was removed and virus inoculum prepared in complete ISE6 cell media (10\% FBS, $10 \%$ tryptose phosphate broth, $0.1 \%$ bovine lipoprotein solution, $\mathrm{pH} 7.5$ ) or $2 \%$ FBS in DMEM was added to cells at a MOI of 0.1. Inoculated cells were incubated at room temperature with gentle rocking for $1 \mathrm{~h}$ before inoculum was removed and monolayers were washed three times with $1 \mathrm{~mL} /$ well sterile PBS. Supernatant from triplicate wells was harvested at 2, 12, 24, 48, 72, 96, 120 and 168 hours post- infection (hpi) and stored at $-80^{\circ} \mathrm{C}$. For NUGV, supernatant was also harvested at $144 \mathrm{hpi}$ and coverslips were harvested at each time point and fixed with $1 \mathrm{~mL}$ of formaldehyde fixative buffer ( $4 \%$ formaldehyde, $0.5 \% \mathrm{v} / \mathrm{v}$ Triton $\mathrm{X}-100$ in PBS) at $4^{\circ} \mathrm{C}$ for 10 minutes and air dried for at least 48 hours before storing at $-20^{\circ} \mathrm{C}$.

Quantification of viral titres in supernatants collected at each time point was determined using a modified $\mathrm{TCID}_{50}$ method described in $(27,38)$. Briefly, 10 -fold dilutions of supernatant (undiluted to $1: 10^{8}$ ) were prepared in $2 \% \mathrm{FBS} / \mathrm{DMEM}$. Each dilution $(50 \mu \mathrm{L})$ was added to 4 replicate wells of a 96-well plate and incubated for 5 days at $37^{\circ} \mathrm{C}$ with $5 \% \mathrm{CO}_{2}$. Flavivirus (GGYV, SREV, WNV KUN NSW2011 strain), NUGV and FCV supernatant titrations were performed on BSR cells, while CMCV titrations were performed on Vero cells. After 5 days, plates containing flaviviruses and FCV were fixed using acetone fixative buffer and virus replication was determined by fixed-cell ELISA using anti-flavivirus E mAb $4 G 2$ or anti-FCV immune serum as described above. NUGV-infected cells were fixed with $150 \mu \mathrm{L} /$ well formaldehyde fixative buffer for 10 minutes at $4^{\circ} \mathrm{C}$ and virus replication was determined by MAVRIC ELISA as described previously (27). For CMCV, virus replication was scored by the presence or absence of CPE. Viral titres in each sample were then calculated using the Reed-Muench guidelines (36). Statistical significance between cell lines at each time point was determined by unpaired, parametric t tests in Graphpad Prism v7.04.

\section{Immunofluorescence assays}

ISE6 cells were seeded on glass coverslips in 24-well plates at $10^{5}$ cells per well one day prior to infection. Cells were infected at $\mathrm{MOI} 0.1$ for $1 \mathrm{~h}$ at room temperature before inoculum was removed and replaced with $1 \mathrm{~mL}$ complete ISE6 medium. Cells were incubated at $34^{\circ} \mathrm{C}$ without $\mathrm{CO}_{2}$. At 7,14 and $28 \mathrm{dpi}$ supernatants were harvested and stored at $-80^{\circ} \mathrm{C}$ and coverslips were fixed by submerging in $100 \%$ icecold acetone for 5 minutes before air drying and storing at $-20^{\circ} \mathrm{C}$. Viral titres in supernatants were determined as described in the previous section. The protocol for $E$ and dsRNA dual-labelling is as follows. All antibodies were diluted in TENTC blocking buffer to previously determined optimal concentrations before use. Coverslips were blocked with $900 \mu \mathrm{L}$ of TENTC blocking buffer for $1 \mathrm{~h}$ at room temperature, followed by incubation with $300 \mu \mathrm{L}$ anti-E mAb $4 \mathrm{G} 2$ at $28^{\circ} \mathrm{C}$ for $1 \mathrm{~h}$. Coverslips were washed thrice with $1 \mathrm{~mL}$ PBS-T (PBS with 0.05\% v/v Tween-20) and incubated with $150 \mu \mathrm{L}$ 1:500 Alexa Fluor 488conjugated goat anti-mouse in TENTC blocking buffer for $1 \mathrm{~h}$ at $28^{\circ} \mathrm{C}$. Another $3 \times$ PBS-T washes were performed followed by addition of $300 \mu \mathrm{L} /$ well MAVRIC hybridoma supernatant (a cocktail of mAbs 3G1 and $2 \mathrm{G} 4$ ) and incubation at $37^{\circ} \mathrm{C}$ for $1 \mathrm{~h}$. Coverslips were again washed three times and Alexa Fluor 594conjugated goat anti-mouse IgM ( $\mu$ chain) diluted 1:500 in blocking buffer was added at $150 \mu \mathrm{L} /$ well at 
$28^{\circ} \mathrm{C}$ for $1 \mathrm{~h}$. Secondary anti-IgM antibody solution was then removed and nuclear staining was performed with $150 \mu \mathrm{L} /$ well Hoechst 33342 for 5 min at room temperature, protected from light. Three final PBST washes were performed, followed by one wash with PBS (without Tween-20) and coverslips were mounted on glass microscope slides using ProLong Gold Antifade mountant (ThermoFisher, Carlsbad, CA, USA). Images were taken on a Zeiss EPI fluorescence microscope.

For comparison of MAVRIC and J2 dsRNA immunolabelling, BSR cells were infected with GGYV, SREV or $W_{N V} V_{\text {NSW2011 }}$ at MOI 0.1 for 5 days and fixed with $1 \mathrm{~mL}$ per well of $4 \%$ formaldehyde in PBS at $4^{\circ} \mathrm{C}$ for 10 minutes and air dried for at least 48 hours before storing at $-20^{\circ} \mathrm{C}$. Prior to labelling, coverslips were thawed and permeabilised by incubation in $1 \mathrm{~mL}$ of $0.5 \%$ Triton X-114 v/v or $0.5 \% \mathrm{w} / \mathrm{v}$ digitonin in PBS for 10 minutes at $4^{\circ} \mathrm{C}$. For the anti-dsRNA time course, coverslips containing BSR cells infected with GGYV at MOI 0.1 were harvested at 12, 24, 48 and 96 hpi and fixed with 100\% acetone as described above. Coverslips were imaged using a Zeiss LSM 510 META confocal microscope.

Immunolabelling for dsRNA was performed on pre-blocked coverslips with $300 \mu \mathrm{L}$ of MAVRIC hybridoma supernatant or $150 \mu \mathrm{L}$ of purified IgG mAb J2 diluted 1:200 in blocking buffer for $1 \mathrm{~h}$ at $37^{\circ} \mathrm{C}$. Coverslips were washed as described above and incubated with $150 \mu \mathrm{L}$ of Alexa Fluor 488-conjugated goat antimouse $(\mathrm{H}+\mathrm{L})$ in diluted 1:500 TENTC blocking buffer for $1 \mathrm{~h}$ at $37^{\circ} \mathrm{C}$. Nuclear staining and mounting was performed as described above. Coverslips were imaged using a Zeiss LSM 510 META confocal microscope.

\section{Sequence annotation and phylogenetic analysis}

Pairwise alignments of the nucleotide and amino acid sequences of archival viruses were performed in Geneious Prime v2019 using MUSCLE or ClustalW algorithms respectively. Sequence annotation for CMCV and FCV was performed using the following platforms: protein topology, Phobius (39); N- and Olinked glycosylation site prediction, NetNGlyc 1.0 and NetOGlyc 4.0 servers (40); domain prediction, HMMER EBI tools web server (41); cleavage site predictions, ProP 1.0 server (42).

Nucleotide coding sequences for NUGV and orbivirus VP1, VP7(T13),T2 and VP5(OC2) proteins were aligned using the MAFFT v7.471 tool via the CIPRES gateway $(43,44)$. Alignments were trimmed to the length of each NUGV segment and JModelTest2 via the CIPRES gateway was used to determine the best model available model for each gene (45). Trees were constructed in MEGA7 using the Maximum Likelihood method based on the Jukes-Cantor model with complete deletion of gaps and missing data with the following models for rates among sites used; for VP1 JC+G with 4 discrete categories, for VP7(13), T2 and VP5(OC2) JC+I. Phylogenetic tests were performed for each node using 1000 bootstrap replicates. Neighbour-Join and BioNJ algorithms were used to generate initial trees based on a matrix of pairwise distances estimated using the Maximum Composite Likelihood (MCL) approach.

Virus-like contigs generated from I. holocyclus transcriptome data (46) were first assessed by a Blastx database search (database: $\mathrm{nr}$, August 2021) and open reading frames were determined using the Translate Tool via the ExPASy website. Amino acid sequences for the nucleocapsid proteins of 
Phlebovirus-like sequence 1 (PVL1) and 3 (PVL3) were aligned with selected phlebovirus nucleocapsid proteins using the MAFFT alignment algorithm via the EBI-EMBL web interface (39). Maximum-likelihood analysis was performed on a MAFFT alignment of 27 sequences trimmed to 338 amino acids before nonconserved regions were removed using GBlocks with less stringent settings (smaller final blocks, gap positions in final blocks and less stringent flanking positions allowed). A final alignment of 99 positions was used for phylogenetic analysis with in MEGA7 using the LG model with 1000 bootstrap replicates. Gamma distribution was used to model evolutionary rate differences among sites with some sites allowed to be evolutionarily invariable $(L G+G+I)$. Neighbour-Join and BioNJ algorithms were applied to a matrix of pairwise distances estimated using the Jones Taylor Thornton (JTT) method to generate the initial trees and topology with superior log likelihood value was selected automatically.

The protein structure of PVL1 and PVL3 nucleocapsid proteins were predicted using the Phyre2 Protein Fold Recognition Server based on an alignment with Toscana virus N protein with $100 \%$ confidence (47). The 3D protein model figures were produced using Chimera software version 1.13.1 (48) and regions were annotated based on domains identified in $(49,50)$.

\section{Results}

\section{Growth and antigenic characterisation of Australian tick-borne flaviviruses.}

The mosquito-borne flavivirus West Nile virus subtype Kunjin $\left(\mathrm{WNV}_{\mathrm{KUN}}\right)$ is routinely used as a positivecontrol for double-stranded RNA production in the MAVRIC system (23). Therefore, for adapting the assay for discovery of tick viruses, we assessed two tick-borne flaviviruses GGYV and SREV for this purpose. Initially we compared the reactivity of a panel of 6 pan-flavivirus anti-E mAbs against $W_{N V_{\text {KUN }}}$, GGYVand SREV-infected BHK cells in fixed-cell ELISA. Five of the six mAbs tested reacted to all three flaviviruses (Table 3). However, we found that the anti-E reactive mAb M2-1E7 bound to GGYV but not SREV (Table 3). Neither GGYV or SREV was detected in infected BHK cells by MAVRIC ELISA after fixation with $20 \%$ acetone fixative buffer or $4 \%$ formaldehyde with $0.5 \%$ Triton $X-100$, despite detecting $W_{N} V_{\text {KUN }}$ under both conditions (Table 3). 
Table 3

Reactivity of pan-flavivirus mAbs and MAVRIC against SREV and GGYV in fixed-cell ELISA.

\begin{tabular}{|c|c|c|c|c|c|}
\hline \multirow[t]{2}{*}{ Antibody } & \multirow[t]{2}{*}{ Reactive protein } & \multicolumn{3}{|c|}{ Reactivity in fixed-cell ELISA a } & \multirow[t]{2}{*}{ Reference } \\
\hline & & $W_{N V}$ & GGYV & SREV & \\
\hline $4 \mathrm{G} 2$ & Envelope & +++ & +++ & ++ & (71) \\
\hline M2-1E7 & Envelope & +++ & ++ & - & (72) \\
\hline $6 \mathrm{~B} 6 \mathrm{C}$ & Envelope & +++ & ++ & + & (73) \\
\hline $3 \mathrm{H} 6$ & Envelope & +++ & ++ & + & (74) \\
\hline 1D1 & Envelope & +++ & ++ & + & $(75)^{b}$ \\
\hline P3H8 & Envelope & +++ & + & + & (76) \\
\hline MAVRIC & dsRNA & ++ & $-c$ & $-c$ & (23) \\
\hline \multicolumn{6}{|c|}{$\begin{array}{l}\text { a }+++, O D_{405 \mathrm{~nm}} \text { equal to or greater than }(\geq) 2 \text { for all tested dilutions; }++, O D_{405 \mathrm{~nm}} \geq 1 \text { for all tested } \\
\text { dilutions; }+, O D_{405 \mathrm{~nm}}<1 \text { for all tested dilutions; - }, \mathrm{OD}_{405 \mathrm{~nm}} \leq \text { mock } \mathrm{OD} \text { for all tested dilutions. }\end{array}$} \\
\hline \multicolumn{6}{|c|}{ b mAb prepared by A.K. Falconar, London School of Hygiene and Tropical Medicine, London, UK. } \\
\hline \multicolumn{6}{|c|}{$\begin{array}{l}{ }^{\mathrm{C}} \text { greater than mock OD but beneath the threshold for a positive score }\left(2 \times \text { mock } \mathrm{OD}_{405 \mathrm{~nm}}\right) \text {. Negative } \\
\text { for MAVRIC in fixed cell ELISA using both } 20 \% \text { acetone and } 4 \% \text { formaldehyde with } 0.5 \% \text { Triton X-100 } \\
\text { fixation. }\end{array}$} \\
\hline
\end{tabular}

To understand the growth dynamics of tick-borne flaviviruses compared to their mosquito-borne relatives, a growth kinetics assay was performed on $\mathrm{WNV}_{\mathrm{KUN}}, \mathrm{GGYV}$ and SREV in vertebrate and tick cells over 7 days. As our preliminary data indicated that prototype $\mathrm{WNV}_{\mathrm{KUN}}$ strain (MRM61C) did not replicate in ISE6 cells, we tested for replication of the more neuroinvasive WNV $_{\text {KUN }}$ strain NSW2011 (51). This assay revealed a similar growth pattern for all three flaviviruses in BSR cells. However, both tick-borne viruses

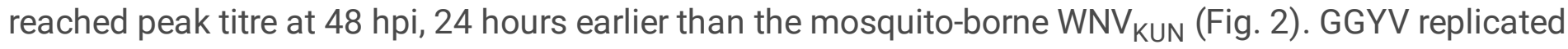
robustly in ISE6 cells, reaching an average peak titre of $10^{7.19} / \mathrm{mL}$ at $72 \mathrm{hpi}$, which was within 1 log of the titre recovered from vertebrate cells at this time point (average titre $10^{7.77} / \mathrm{mL}$ ) (Fig. 2a). While the growth curve of SREV in ISE6 cells mirrored that of the virus in BSRs, viral titres recovered from the tick cells were significantly lower at all time points, with more than 2 logs difference between the peak titres recovered from each cell line (ISE6: $10^{4.97} / \mathrm{mL}$, BSR $10^{7.13} / \mathrm{mL}$ ) (Fig. 2b). No infectious virus could be detected in supernatant from $\mathrm{WNV}_{\mathrm{KUN}}$-infected tick cells from $72 \mathrm{hpi}$ onwards. However, a small amount of virus (average titre $10^{1.8} / \mathrm{mL}$ ) was detected in supernatant harvested from three replicate wells at both 12 and $24 \mathrm{hpi}$ followed by a decline at $48 \mathrm{hpi}$, indicating that some viral replication may occur in these cells during the early stages of infection (Fig. 2c). 


\section{Detection of double-stranded RNA in tick-borne flavivirus replication}

While our growth kinetics data indicated that GGYV and SREV replicated in both tick and vertebrate cell lines, we were unable to detect dsRNA in cells infected with either virus using the MAVRIC ELISA. To investigate this further we performed an immunofluorescence assay (IFA) on ISE6 cells infected with GGYV or SREV. Infectious virus was detected in supernatant from cells infected with SREV at 7, 14 and 28 dpi, but only from GGYV-infected cells at 7 and 14 dpi (Fig. 3). Envelope protein could be detected by IFA for both viruses at all time points; however, no dsRNA was detected in these cells by co-labelling with MAVRIC (Fig. 3).

To confirm that the lack of dsRNA immunolabelling was not related to our anti-dsRNA antibodies, we compared detection of dsRNA in SREV-, GGYV- and WNV KUN -infected cells using MAVRIC (mAbs $3 G 1$ and 2G4) and the commercial anti-dsRNA antibody J2 (IgG, Scicons) (52). While both antibodies detected dsRNA in WNV KUN $^{-i n f e c t e d ~ B S R ~ c e l l s ~ a t ~} 5$ dpi, neither J2 nor MAVRIC detected significant amounts of dsRNA in SREV- and GGYV-infected cells at this time point (Fig. 4). This result was also observed in cells fixed and permeabilised using $4 \%$ formaldehyde with $0.5 \%$ digitonin (Additional file 1: Figure S1).

As we were unable to detect dsRNA by IFA or ELISA at 5 dpi onwards, we performed anti-dsRNA labelling on GGYV-infected BSRs at earlier time points. This analysis showed that dsRNA was not detected using J2 at 24, 48 and 96 hpi (Fig. 5). However, a small percentage of cells with perinuclear dsRNA signal were observed at $12 \mathrm{hpi}$ (Fig. 5).

\section{Growth kinetics and in situ detection of NUGV in vertebrate and tick cells}

NUGV is an orbivirus that was isolated from I. uriae ticks collected at Macquarie Island (9). We first assessed its ability to replicate and produce sufficient levels of accessible viral dsRNA in inoculated BSR and ISE6 cells for detection by MAVRIC.

Growth kinetics analysis showed NUGV replicated to an average peak titre of $10^{7.62} / \mathrm{mL}$ by $24 \mathrm{hpi}$ in BSR cells. This was followed by a steady decline in titre over the next 6 days (Fig. 6a), which coincided with overt cytopathic effect in these cells. In ISE6 cells, an average peak titre of $10^{6.47} / \mathrm{mL}$ was detected at 96 hpi, with titres staying relatively stable from this point on (Fig. 6a). Infected cells were fixed at each time point and immunolabelled for dsRNA using MAVRIC. Significant amounts of dsRNA were first detected in BSR cells at $24 \mathrm{hpi}$, coinciding with the peak titre of the virus (Fig. 6b). In ISE6 cells, a strong dsRNA signal was detected from 48 hpi onward (Fig. 6c).

\section{Genomic sequence analysis of NUGV}


Although NUGV was first isolated in 1972 (9), to date no sequence analysis has been conducted on the viral genome. We performed deep sequencing on an archival stock of the prototype NUGV strain (MI14847) and obtained partial sequence for all 10 genome segments (Table 4). Pairwise alignments with available sequence for SBaV, an orbivirus isolated from I. uriae collected on Macquarie Island in 2002 (15), showed high similarity at both the nucleotide (96.4 - 98.4\%) and amino acid (97-100\%) levels for VP4 (CaP), VP5 (OC2), NS2 (ViP) and NS3 (Table 4). NUGV also shares approximately 75\% nucleotide and $90-91 \%$ amino acid identity with the T2 and T13 sequences of Great Island virus (GIV) (Table 4). Phylogenetic analysis of the nucleotide sequences of VP1 genes show that NUGV groups with GIV within the tick-borne orbivirus clade (Fig. 7a), This grouping was also supported by phylogenetic trees constructed from the nucleotide sequences of the T2 and VP7 (T13) structural genes (Additional file 1: Figure S2). Maximum likelihood analysis of the nucleotide sequence of VP5 (OC2) show that NUGV and SBaV cluster with other members of the GIV species (Fig. 7b). 
Table 4

Summary of sequence data generated for Nugget virus

\begin{tabular}{|c|c|c|c|c|c|c|}
\hline $\begin{array}{l}\text { Expected } \\
\text { segment } \\
\text { a }\end{array}$ & $\begin{array}{l}\text { Gene } \\
\text { b }\end{array}$ & $\begin{array}{l}\text { Accession } \\
\text { number }\end{array}$ & $\begin{array}{l}\text { Segment } \\
\text { length } \\
\text { (nt) }\end{array}$ & $\begin{array}{l}\text { Protein } \\
\text { length } \\
\text { (aa) }\end{array}$ & $\begin{array}{l}\text { \% Pairwise } \\
\text { identity with GIV } \\
\text { (nt/aa) }\end{array}$ & $\begin{array}{l}\text { \% Pairwise identity } \\
\text { with SBaV (nt/aa) }\end{array}$ \\
\hline 1 & $\begin{array}{l}\text { VP1 } \\
\text { (Pol) }\end{array}$ & OK396633 & 3776 & 1258 & $69.4 / 80.3$ & - \\
\hline 2 & $\begin{array}{l}\text { VP3 } \\
\text { (T2) }\end{array}$ & OK396634 & 2559 & 852 & 74.9/90.4. & - \\
\hline 3 & $\begin{array}{l}\text { VP4 } \\
\text { (CaP) }\end{array}$ & OK396635 & 1645 & 547 & $65.3 / 71.9$ & $96.4 / 97.0$ \\
\hline 4 & $\begin{array}{l}\text { NS1 } \\
\text { (TuP) }\end{array}$ & OK396636 & 1548 & 515 & $63.9 / 69.9$ & - \\
\hline 5 & $\begin{array}{l}\text { VP2 } \\
\text { (OC1) }\end{array}$ & OK396637 & 1458 & 486 & $53.4 / 59.7$ & - \\
\hline 6 & $\begin{array}{l}\text { VP5 } \\
\text { (OC2) }\end{array}$ & OK396638 & 1229 & 409 & $66.0 / 70.4$ & $98.4 / 99.0$ \\
\hline 7 & $\begin{array}{l}\text { VP7 } \\
\text { (T13) }\end{array}$ & OK396639 & 988 & 329 & $75.6 / 91.2$ & - \\
\hline 8 & $\begin{array}{l}\text { NS2 } \\
\text { (ViP) }\end{array}$ & OK396640 & 1143 & 372 & $68.3 / 76.1$ & 98.0/99.2. \\
\hline 9 & $\begin{array}{l}\text { VP6 } \\
\text { (Hel) }\end{array}$ & OK396641 & 959 & 314 & $64.9 / 51.4$ & - \\
\hline 10 & NS3 & OK396642 & 566 & 157 & $66.9 / 72.0$ & $98.0 / 100.0$ \\
\hline
\end{tabular}

a Segment predictions are based on GIV segment designations (77).

${ }^{b}$ Viral protein designations (VP) are based on Bluetongue virus nomenclature as per (78). Pol, RNAdependent RNA polymerase; $T 2$, conserved major subcore protein with $\mathrm{T}=2$ symmetry; CaP, capping enzyme; TuP, tubule forming protein; $\mathrm{OC} 1$, outer capsid protein 1; $\mathrm{OC2}$, outer capsid protein 2; major core protein with $\mathrm{T}=13$ symmetry; ViP, viral inclusion body protein; Hel, ssRNA- and dsRNA-binding helicase.

c GIV nucleotide sequences (NC_014522 to NC_014531), amino acid sequences (YP_003896058 to YP_003896068).

d SBaV nucleotide sequences (EU685329 to EU685333), amino acid sequences (ACD38335 to ACD38337 and ACD38339)

\section{Characterisation of CMCV}

We previously isolated CMCV from I. uriae ticks collected in 2002 from Macquarie Island (15) and reported that it genetically clustered with other phleboviruses and was genetically similar to PPV, a virus 
previously isolated from the same tick species collected on the island almost 30 years earlier (9). However, only the S segment of CMCV was originally sequenced. To complete the characterisation of this virus and its genetic relationships to other tick-borne viruses found in the same region, we performed next generation sequencing on a stock of CMCV. This yielded full-length $L$ segment and near full-length sequence for the $\mathrm{M}$ segment (excluding the first 10 bases of the $5^{\prime}$ and last 4 bases of $3^{\prime}$ genomic termini). From this, the complete coding sequence (CDS) of the $L$ protein and glycoprotein precursor were identified and annotated (Fig. 8a). The nucleotide sequences of the $L$ and $M$ segment shared $97.4 \%$ and $94.4 \%$ similarity with PPV. While the L protein and glycoprotein precursor shared greater than $99 \%$ amino acid similarity with this virus (Fig. 8b). The S segment of CMCV that had been generated previously shares $95.7 \%$ nucleotide similarity with the S segment of PPV and 100 and $96.2 \%$ amino acid similarity with PPV nucleocapsid and non-structural proteins respectively (Fig. 8b) (15).

Protein analysis of purified CMCV showed the Gn and Gc glycoproteins run at apparent molecular weights of 47.2 and $53.2 \mathrm{kDa}$ (Fig. 9a). A third band was identified at $258.3 \mathrm{kDa}$ which may represent viral ribonucleoprotein complexes (RNP). Growth kinetics analysis showed that CMCV replicated to significantly higher titres in ISE6 cells at $72 \mathrm{hpi} \mathrm{compared} \mathrm{to} \mathrm{BSR} \mathrm{cells} \mathrm{(Fig.} \mathrm{9b).} \mathrm{Peak} \mathrm{titres} \mathrm{were} \mathrm{detected}$ in both cell lines by $120 \mathrm{hpi}(5 \mathrm{dpi})$ with BSR cells $\left(10^{6.91} / \mathrm{mL}\right)$ surpassing that of ISE6 cells $\left(10^{6.63} / \mathrm{mL}\right)$ (Fig. 9b).

\section{Genetic characterisation of FCV}

We performed similar analyses on FCV, a nairovirus isolated from I. uriae also collected at Macquarie Island in 2002 (9). Complete open reading frames (ORFs) for all three genome segments were generated by next generation sequencing (Fig. 10a). The newly obtained $L$ segment sequence shared $97.7 \%$ nucleotide and $99.2 \%$ amino acid similarity with the partial $L$ segment sequence previously reported (Fig. 10b) (15). All three segments also shared high similarity at both the nucleotide $(97.8-99.6 \%)$ and amino acid (99.6 - 100\%) levels with the sequence of the prototype isolate of TAGV (MI14850), isolated from the same tick species collected on Macquarie Island in 1972 (Fig. 10b) (14). FCV appears less closely related to a new variant of TAGV identified in I. uriae ticks collected in 2017 from Antarctica, with $81.4 \%$ nucleotide $94 \%$ amino acid sequence shared across the $L$ segment, the most conserved of the three segments (Fig. 10b).

\section{In vitro characterisation of FCV}

We observed that after passaging FCV in ISE6 cells, the virus caused inconsistent CPE when inoculated onto mammalian cells, and therefore could not be reliably quantified by CPE scoring. To circumvent this, we purified the virus for immunization of mice to generate virus specific immune serum. As the pathogenicity of FCV in mice and humans is unknown, the virus was inactivated by the addition of binary ethylenimine (BEI) to cell culture supernatant prior to purification. SDS-PAGE analysis of the purified virions revealed two predominant bands at apparent molecular weights of 261.2 and $54.8 \mathrm{kDa}$ (Fig. 11a). Both bands were determined by mass spectrometry to contain the nucleocapsid (N) protein (Fig. 11a, 
Additional file 2: Dataset S1). Three additional bands were identified at apparent molecular weights of $181.2,72.2$ and $62.2 \mathrm{kDa}$ which presumably contain the $\mathrm{RdRp}(\mathrm{L}), \mathrm{Gc}$ and $\mathrm{Gn}$ glycoproteins respectively (Fig. 11a).

Mouse immune serum raised to this virus preparation was assessed in western blot and showed reactivity to the N protein in FCV-infected cell lysate (Fig. 11b). Titration of the immune serum on FCV and TAGV infected BSRs in fixed-cell ELISA showed the serum detected both viruses equally well up until an end point dilution of 1:6400 (Fig. 11C).

Growth kinetics analysis of FCV showed that the virus replicated rapidly in the first 24 hours followed by a plateau in both vertebrate and tick cell lines (Fig. 11d). In BSR cells peak titre was detected at $96 \mathrm{hpi}$ followed by a decline at 120 and $168 \mathrm{hpi}$. FCV replicated less efficiently in ISE6 cells with recovered titres being 2-3 logs lower than the titres from BSR cells at time points $24-120 \mathrm{hpi}$ (Fig. 11d). However, peak titre in this cell line was only detected at $168 \mathrm{hpi}(7 \mathrm{dpi})$, suggesting that productive infection in ISE6 cells may persist past the time points sampled in this study.

\section{Virus-like sequences in transcriptome data of I. holocyclus ticks}

We were given access to viral sequence contigs previously assembled from transcriptome sequencing of I. holocyclus ticks collected in South-East Queensland (QLD) and Northern New South Wales (NSW, Table 5) $(46,53)$. Our analysis focussed primarily on contigs with similarity to RNA viruses and excluded any sequences of the tick-specific IhIV which we have reported previously (34). While sequence of IhIV was detected in five of the 6 data sets (34), only three data sets yielded potential arbovirus-like sequences (Table 5, Fig. 12). 
Table 5

Summary of transcriptome data analysed for viral sequences

\begin{tabular}{|c|c|c|c|c|}
\hline $\begin{array}{l}\text { Sequencing } \\
\text { technology }\end{array}$ & Location & Year & $\begin{array}{l}\text { Description of } \\
\text { collection }\end{array}$ & Sample type \\
\hline 454-ion torrent & Pinjara Hills, QLD & 2010 & $\begin{array}{l}\text { Feeding on } \\
\text { bandicoots }\end{array}$ & $\begin{array}{l}\text { Salivary } \\
\text { glands }\end{array}$ \\
\hline 454-ion torrent & Suffolk Park, NSW & 2010 & Unfed adults & Whole ticks \\
\hline Illumina ${ }^{a}$ & Wynnum-Manly, QLD & 2012 & $\begin{array}{l}\text { Paralysed cats and } \\
\text { dogs }\end{array}$ & Viscera \\
\hline Illumina & Wynnum-Manly, QLD & 2012 & $\begin{array}{l}\text { Paralysed cats and } \\
\text { dogs }\end{array}$ & $\begin{array}{l}\text { Salivary } \\
\text { glands }\end{array}$ \\
\hline Illumina & $\begin{array}{l}\text { South-east QLD \& Northern } \\
\text { NSW }\end{array}$ & 2013 & $\begin{array}{l}\text { Paralysed cats and } \\
\text { dogs }\end{array}$ & Viscera \\
\hline Illumina & $\begin{array}{l}\text { South-east QLD \& Northern } \\
\text { NSW }\end{array}$ & 2013 & $\begin{array}{l}\text { Paralysed cats and } \\
\text { dogs }\end{array}$ & $\begin{array}{l}\text { Salivary } \\
\text { glands }\end{array}$ \\
\hline
\end{tabular}

From the viscera of ticks collected from paralysed cats and dogs, three distinct sequences were identified which resembled the phlebovirus nucleocapsid gene (Fig. 12). These sequences will be referred to from herein as PVL 1, 2 and 3. PVL1 and 2 were identified in ticks collected in the Wynnum-Manly region of QLD, while PVL3 was identified in pooled viscera of ticks collected in Northern NSW and South-east QLD (Fig. 12). Only one sequence, PVL1 was identified in datasets from paired viscera and salivary glands (Fig. 12). PVL1 and 3 showed sequence homology to two variants of Ronne virus, a novel phlebovirus identified in I. uriae ticks from Antarctica and Norway (Table 6) $(54,55)$. These sequences also shared $66.7 \%$ nucleotide and $76.9 \%$ amino acid identity with one another. PVL2 showed homology to Timbillica virus, a novel virus identified in I. holocyclus ticks from Southern NSW (20) (Table 6). Finally, a small contig with similarity to the rhabdovirus RdRp gene was identified in sequence data from salivary glands, but not paired viscera, of ticks collected in Wynnum-Manly, QLD (Fig. 12, Table 6). 
Table 6

Closest matches to I. holocylcus virus-like sequences by Blastx database search

\begin{tabular}{|c|c|c|c|c|c|c|c|}
\hline \multirow{2}{*}{$\begin{array}{l}\text { Sequence } \\
\text { name }\end{array}$} & \multirow{2}{*}{$\begin{array}{l}\text { Sequence } \\
\text { length (nt/aa) }\end{array}$} & \multicolumn{6}{|c|}{ Blastx search result } \\
\hline & & $\begin{array}{l}\text { Closest } \\
\text { relative }\end{array}$ & $\begin{array}{l}\text { Accession } \\
\text { no. }\end{array}$ & Gene & $\%$ ID & $\%$ & $\begin{array}{l}\text { E- } \\
\text { value }\end{array}$ \\
\hline $\begin{array}{l}\text { Rhabdo- } \\
\text { like }\end{array}$ & $337 / 65$ & $\begin{array}{l}\text { Manly } \\
\text { virus }\end{array}$ & AYP67529 & $\mathrm{RdRP}$ & 37.86 & 91 & $\begin{array}{l}7 e- \\
13\end{array}$ \\
\hline PVL1 & $1003 / 237$ & $\begin{array}{l}\text { Ronne } \\
\text { virus }\end{array}$ & QKK82905 & Nucleocapsid & 38.96 & 69 & $\begin{array}{l}2 \mathrm{e}- \\
44\end{array}$ \\
\hline PVL2 & $269 / 69$ & $\begin{array}{l}\text { Timbillica } \\
\text { virus }\end{array}$ & AYP67565 & Nucleocapsid & 35.53 & 84 & $\begin{array}{l}3 e- \\
05\end{array}$ \\
\hline PVL3 & $711 / 237$ & $\begin{array}{l}\text { Ronne } \\
\text { virus }\end{array}$ & QIS88056 & Capsid & 38.53 & 97 & $\begin{array}{l}8 e^{-} \\
52\end{array}$ \\
\hline
\end{tabular}

Sequence analysis of two phlebovirus-like sequences from I. holocyclus ticks

PVL1 and 3 both contained a 711 nucleotide-long ORF encoding a 237 amino acid nucleocapsid (NC)-like protein (Fig. 13a, b). This protein shares homology at both sequence and structural levels with phlebovirus N proteins (Fig. 13b, Additional file 1: Figure S3). However, both proteins lacked alpha helices 1 and 2 which make up the N-terminus arm shown to be responsible for stabilisation of Rift Valley fever and Toscana virus nucleoprotein hexamers $(49,56)$ (Fig. 13b, Additional file 1: Figure S3). PVL3 contained all conserved structural elements found in the globular domains of phlebovirus nucleocapsids (alpha helices 3 - 13). In PVL1, alpha helix 3 (a3) was substituted for a beta strand (Fig. 13B, Additional file 1: Figure S3). PVL1 and 3 also contained a second short ORF in the reverse orientation (Fig. 13a). The resulting proteins from this ORF share $64 \%$ amino acid similarity with one another but do not show any conservation to known proteins by blast or hmmer database searches (Fig. 13a, c).

Maximum-likelihood analysis performed on the NC proteins of PVL1, 3 and selected phleboviruses suggested that PVL1 and 3 cluster with other virus sequences identified in I. uriae and I. holocyclus ticks from the Southern hemisphere (Fig. 13d).

Attempts to isolate viruses from I. holocyclus ticks

Primers were designed to test for each of the viral sequences identified above in homogenates of $I$. holocyclus ticks collected in northern NSW between 2000-2001. All four sequences were detected by RTPCR in ticks of this cohort (Table 7). The amplified sequences shared high sequence similarity with the original sequences, however, attempts to amplify additional sequence from these samples using degenerate primers and next generation sequencing were unsuccessful. 
Table 7

Detection of virus-like sequences in I. holocyclus homogenates

\begin{tabular}{|lllll|}
\hline $\begin{array}{l}\text { Sequence } \\
\text { name }\end{array}$ & $\begin{array}{l}\text { Accession } \\
\text { no. }\end{array}$ & $\begin{array}{l}\text { Product } \\
\text { size (bp) }\end{array}$ & $\begin{array}{l}\text { Homogenate } \\
\text { (positive/tested) }\end{array}$ & $\begin{array}{l}\text { Nucleotide similarity to original } \\
\text { sequence (\%) }\end{array}$ \\
\hline $\begin{array}{l}\text { Rhabdo- } \\
\text { like }\end{array}$ & OK396646 & 221 & $4 / 10$ & 100.0 \\
\hline PVL1 & OK396643 & 623 & $3 / 10$ & 99.84 \\
\hline PVL2 & OK396644 & 142 & $5 / 6$ & 100.0 \\
\hline PVL3 & OK396645 & 388 & $5 / 6$ & 99.74 \\
\hline
\end{tabular}

As no further sequence could be amplified from homogenates, attempts were made to isolate viruses in cell culture. Three serial passages of RT-PCR positive homogenates were performed on cell lines derived from rodent (BHK), marsupial (OK) and tick (ISE6) origins. However, no viral isolates were identified by RTPCR analysis or CPE scoring.

\section{Discussion}

The field of tick-borne virus research in Australia is experiencing a new wave of focus due to advances in metagenomic sequencing technologies $(17,20,57)$. However, in vitro characterisation of newly identified viruses is currently lacking. A wealth of information is available from archival virus isolates, most of which were first reported between 1975 and 1985 . We sought to provide additional characterisation of five tick-borne viruses isolated from seabird-associated ticks around Australia, in order to establish a system for virus discovery and isolation based on the MAVRIC system (23).

We performed growth kinetics analysis on five Australian tick-borne viruses in vertebrate and tick cells. This analysis shows that all five viruses replicate rapidly and to high titres in the rodent derived BSR cell line. The mammalian tick-borne flavivirus GGYV, orbivirus NUGV and phlebovirus CMCV replicated robustly in the I. scapularis-derived ISE6 cells, reaching peak titres within $1-1.5$ log of their peak titre in vertebrate cells. In contrast to GGYV, the seabird tick-associated flavivirus SREV replicated to significantly lower titres in ISE6 cells. Although SREV has been isolated from the Australian Ixodes species I. eudyptidis, the CSIRO4 strain used in this study is derived from the soft tick 0 . capensis (11). Furthermore, the closest relative of SREV, Meaban virus has been primarily isolated from Onithodoros species ticks possibly indicating a preference of these viruses for an Ornithodoros vector $(58,59)$. If this is the case, an Ornithodoros-derived cell line may provide a better alternative for growth of these viruses (60). Interestingly, SREV could still be recovered from ISE6 cells four weeks after infection suggesting an ability for this virus to persist in an Ixodes-derived cell line longer than GGYV, an Ixodes tick-borne flavivirus. FCV, a nairovirus isolated from I. uriae, also produced significantly lower titres in ISE6 cells between 1 and $5 \mathrm{dpi}$. However, an increase in titre at $7 \mathrm{dpi}$ may indicate that peak replication of this virus occurs after the time points sampled in this study. In line with this, growth kinetics of another Ixodesborne nairovirus, Hazara virus, in ISE6 cells showed the virus reached peak titre at $8 \mathrm{dpi}(61)$. 
As the MAVRIC system has been successfully used for detection of mosquito-borne flaviviruses $(23,25)$, we first assessed its use with the tick-borne flaviviruses GGYV and SREV. Despite replication of both tickborne flaviviruses in BSR and ISE6 cells, dsRNA could not be detected in either cell line by IFA or ELISA. This unexpected finding was confirmed using the commercial anti-dsRNA antibody J2, which has successfully been used to detect dsRNA in Langat virus-infected ISE6 and Vero cells permeabilised with $0.1 \%$ Triton X-100 (62) and TBEV-infected vertebrate cells following permeabilization with either $0.1 \%$ Triton X-100 or $0.05 \%$ saponin $(63,64)$. We examined multiple methods of cell permeabilisation including $20 \%$ acetone and $0.5 \%$ Triton X-100 detergent in ELISA and $100 \%$ acetone, Triton X-114 and digitonin in IFA. All of the conditions tested in this study allowed for visualisation of dsRNA in cells infected with the mosquito-borne flavivirus $W_{N V} V_{K U N}$, but not those infected with GGYV or SREV. Flavivirus replication requires the production of dsRNA as intermediates for the generation of nascent RNA genomes. This process is sequestered within invaginations of the host cell membranes which house the viral proteins responsible for RNA synthesis $(62,65)$. Considering that this process has been demonstrated in both mosquito- and tick-borne flavivirus infection $(64,66)$, it seems likely that the lack of dsRNA detected in GGYV and SREV-infected cells is a result of poor exposure of the replicative intermediates during immunolabeling, rather than an absence of dsRNA. Furthermore, detection of dsRNA in GGYV-infected cells at $12 \mathrm{hpi}$ but not at later time points could suggest that the virus replication complexes become less permeable as infection progresses. Previously we have demonstrated that $20 \%$ acetone fixation does not sufficiently expose dsRNA during dengue virus-infection, however in this instance dsRNA could be detected following fixation with $100 \%$ acetone (23). In lieu of MAVRIC, our antigenic analyses identified five pan-flavivirus mAbs reactive to the E-protein that can be used for detection of both a mammalianand a seabird-associated tick flavivirus. Furthermore, we found that one mAb, M2-1E7, could be used to distinguish between the two viruses.

In contrast to our findings with SREV and GGYV, the archival tick-borne orbivirus NUGV was detectable using our anti-dsRNA mAbs from 12 hpi in vertebrate cells and 48 hpi in tick cells. In this study we also report the first genomic sequence data for NUGV. Our data shows that NUGV clusters with the GIV species, consistent with previous serological data (9). Furthermore, NUGV shares high nucleotide (96$98 \%$ ) and amino acid (97-100\%) similarity with the available sequences for Sandy Bay virus SBaV encompassing the outer capsid protein VP5, the capping enzyme VP4 and two non-structural proteins NS2 and NS3. As these genes are typically less conserved between orbiviruses $(67,68)$, the high level of sequence similarity indicates that SBaV is likely a contemporary isolate of NUGV. However, sequencing of the additional genome segments of $\mathrm{SBaV}$ is required to confirm this.

We generated complete ORF sequences for the $L$ and $M$ segments of the phlebovirus CMCV and all three segments of the nairovirus FCV. Both viruses share high similarity with archival viruses isolated from Macquarie Island 27 - 30 years earlier $(9,10)$. This data suggests that these viruses represent conventional isolates of the phlebovirus PPV and nairovirus TAGV. Furthermore, we demonstrated that serum raised to FCV detected both FCV and TAGV equally well in fixed-cell ELISA. The closeness of FCV to the original TAGV isolate is particularly interesting considering recent detections of two TAGV variants 
in I. uriae ticks from Antarctica in 2017 and 2018 which share $94-99 \%$ nucleotide identity to one another but are divergent from the prototype TAGV strain and FCV $(54,55)$.

Access to transcriptome sequencing of $I$. holocylcus ticks allowed us to identify four virus-like sequences. These sequences were all related to, but distinct from, sequences previously described in metatranscriptomic survey of I. holocyclus ticks collected in Sydney and Southern NSW between 2016 and 2017 (20). RT-PCR analysis of I. holocyclus ticks collected in Northern NSW 10-12 years earlier confirmed the presence of all four sequences. However, attempts to generate additional sequence or obtain isolates in cell culture were unsuccessful. Two sequences, Phlebovirus-like (PVL) sequence 1 and 3 , encoded proteins with homology to phlebovirus nucleocapsid proteins. Phylogenetic analysis of these proteins indicated that they clustered with other tick-specific phlebovirus sequences identified in the southern hemisphere. However, both proteins contained a truncated $\mathrm{N}$-terminus contrasting with findings for other recently identified tick phleboviruses which have significantly larger nucleocapsid proteins with elongated $\mathrm{N}$-terminal domains $(20,54,69)$. At this stage it is unclear whether these sequences represent viruses or viral integrations. However, the presence of Phlebovirus-like sequence 1 in the viscera and salivary glands of ticks from Queensland is particularly interesting in the context of IhIV which was also identified in both the salivary glands and viscera of I. holocyclus ticks but did not replicate in ISE6 cells (34). Interestingly neither the four virus-like sequences described in this study, nor their relatives described in (20), were identified in a recent meta-transcriptomic study performed on unfed adult $I$. holocyclus ticks collected in Northern NSW (21).

\section{Conclusion}

In this study we performed extended characterisation on five archival Australian tick viruses in vertebrate and tick cells to discern whether our mosquito-virus discovery method could be adapted for Australian ticks. Our findings indicate that the established I. scapularis ISE6 cell line can support replication of tickborne arboviruses, including a flavivirus from an Argasid tick. Furthermore, we have demonstrated that a combined approach of anti-dsRNA and pan-flavivirus mAbs should allow for identification of reoviruses and flaviviruses from Australian ticks. However, the ability of a northern hemisphere-derived tick cell line to support replication of Australian tick-specific viruses is still unclear. Cell lines derived from Australian native ticks may be necessary for future characterisation of tick-specific viruses in this region. Finally, next generation sequencing of NUGV, CMCV and FCV further highlight the need for sequencing of archival viruses to prevent isolates of a single virus receiving multiple names.

\section{Abbreviations}

DSCATT: Debilitating Symptoms Complex Attributed to Ticks; CSIRO: Commonwealth Science and Industrial Research Organisation; SREV: Saumarez Reef virus; GGYV: Gagdets Gully virus; WNV $\mathrm{KUN}_{\text {: West }}$ Nile Virus subtype Kunjin; CMCV: Catch-me-cave virus; PPV: Precarious Point virus; FCV: Finch Creek virus; TAGV: Taggert virus; NUGV: Nugget virus; SBaV: Sandy Bay virus; GIV: Great Island virus; MAVRIC: Monoclonal antibodies to viral RNA intermediates in cells; SDS-PAGE: Sodium dodecyl sulphate- 
polyacrylamide gel electrophoresis; PBS: phosphate buffered saline; PBS-T: phosphate buffered saline with $0.05 \%$ V/V Tween-20; VINHV: Vinegar Hill virus; ISE6: Ixodes scapularis cell line; OK: Opossum kidney cell line; BHK: baby hamster kidney cell line; BSR: clone of BHK cell line; Vero: African green monkey kidney cell line; C6/36: Aedes albopictus mosquito cell line; PLV: Phlebovirus-like sequence; QLD: Queensland; NSW: New South Wales.

\section{Declarations}

\section{Acknowledgments}

We wish to thank the Australian Antarctic Division, and the National Parks and Wildlife Service, for their assistance in the collection of ticks on Macquarie Island. We are grateful to Ulrike Munderloh (University of Minnesota, USA) for providing us with the ISE6 cell line and thorough advice on its culture. We thank Dr Jeff Grabowski (Rocky Mountain laboratories, NIH, USA) and Leslie Bell-Sakyi (Pirbright Institute, UK) for their support and advice with regards to the culture of ISE6 cells. We thank Dr Toby St. George for advice and helpful discussion and Dr John Askov (Queensland University of Technology, Australia) for providing us with archival stocks of Nugget and Taggert viruses. We are grateful to Zoetis for allowing us access to I. holocyclus ticks from northern NSW and to Ala E Tabor (University of Queensland, Australia) and Elanco Animal Health for providing us with the virus-like contigs from I. holocyclus transcriptome sequencing. QIMR Berghofer MRI is now the custodian of the "Doherty Virus Collection" which now contains inter alia CMCV, GGV, FCV and SBaV. AS, JH-P and RAH are members of the Global Virus Network AIDRC Center of Excellence (https://gvn.org/gvn-centers-of-excellence/asiaaustralia/australia/) and we acknowledge their ongoing support for virology research.

\section{Funding}

This research was funded by an Australian Research Council Linkage Project Grant (LP160100200) and National Health and Medical Research Council (NHMRC) of Australia Project grant (APP1164216). COB, NDN and JEH were supported by an Australian Government Research Training Program scholarship (https://ppl.app.uq.edu.au/content/uq-and-rtp-research-scholarships-procedures) via the Faculty of Medicine at the University of Queensland (UQ). JEH also received funding from the Global Change Institute/Graduate School at UQ (https://graduate-school.uq.edu.au/current-students/globalchange-scholars-program). AS holds an NHMRC Investigator grant (APP1173880). The funders had no role in study design, data collection and analysis, decision to publish, or preparation of the manuscript.

\section{Availability of data and materials}

The sequences described in this paper have been submitted to Genbank under the following accession numbers: NUGV (OK396633 - OK396642), CMCV (OK493375 \& OK493376), FCV (OK493377 - OK493379), I. holocyclus virus-like sequences (OK396643 - OK396646). The I. holocyclus transcriptome data sets 
have been published previously and can be found below: https://www.ncbi.nlm.nih.gov/genbank/, GIBQ01000000.1.

\section{Authors' contributions}

CAO designed the study, performed growth kinetics, performed phylogenetic and sequence analysis on all sequences in the manuscript, designed primers for virus-like sequence RT-PCR, performed antigenic analysis of FCV and tick-borne flaviviruses and detection of dsRNA. BH performed library preparation and sequencing of NUGV, CMCV and FCV. DW provided NUGV and performed assembly of NUGV, CMCV and FCV. JEH performed RT-PCR screening on I. holocyclus ticks, performed validation of virus-like sequences. HBO provided guidance on inactivation and purification of FCV, performed immunisation of mice with FCV and collection of blood and was a major contributor in writing the manuscript. SHM provided $I$. holocyclus ticks and assisted in study design and performed screening. CLP performed mass spectrometry analysis of FCV. JJH performed FCV growth kinetics. DP performed NUGV growth kinetics. NDN performed culture of tick-borne flaviviruses and contributed to writing of manuscript. BLS performed mass spectrometry on FCV. AS provided FCV and CMCV and contributed to writing of the manuscript. JHP designed the study and provided supervision. RAH designed the study and provided supervision and contributed to writing of the manuscript. All authors performed proof reading and assisted with drafting. All authors read and approved the final manuscript.

\section{Ethics approval and consent to participate}

Animal work was performed under project AEC \#SCMB/329/15/ARC.

\section{Consent for publication}

Not applicable

\section{Competing interests}

Monoclonal antibody $3 \mathrm{G} 1$ is available for purchase via Merck. Monoclonal antibody $2 \mathrm{G} 4$ is available for purchase via Mozzy Mabs - https://eshop.uniquest.com.au/mozzy-mabs/.

\section{References}

1. Knope K, Doggett SL, Jansen CC, Johansen CA, Kurucz N, Feldman R, et al. Arboviral diseases and malaria in Australia, 2014-15: Annual report of the National Arbovirus and Malaria Advisory Committee. Communicable Diseases Intelligence (2018). 2019;43.

2. Dehhaghi M, Kazemi Shariat Panahi H, Holmes EC, Hudson BJ, Schloeffel R, Guillemin GJ. Human Tick-Borne Diseases in Australia. Front Cell Infect Microbiol. 2019;9:3.

3. Madani TA. Alkhumra virus infection, a new viral hemorrhagic fever in Saudi Arabia. J Infect. 2005;51(2):91-7. 
4. Vorou R, Pierroutsakos IN, Maltezou HC. Crimean-Congo hemorrhagic fever. Curr Opin Infect Dis. 2007;20(5):495-500.

5. Savage HM, Godsey MS, Jr., Lambert A, Panella NA, Burkhalter KL, Harmon JR, et al. First detection of Heartland virus (Bunyaviridae. Phlebovirus) from field collected arthropods. Am J Trop Med Hyg. 2013;89(3):445-52.

6. Chumakov MP, Sarmanova ES, Bychkova MV, Bannova GG, Pivanova GP, Karpovich LG, et al. Identification of Kemerovo tick-borne fever virus and its antigenic independence. Fed Proc Transl Suppl. 1964;23:852-4.

7. Wang M, Zuo J, Hu K. Identification of severe fever with thrombocytopenia syndrome virus in ticks collected from patients. Int J Infect Dis. 2014;29:82-3.

8. Barker SC, Walker AR, Campelo D. A list of the 70 species of Australian ticks; diagnostic guides to and species accounts of Ixodes holocyclus (paralysis tick), Ixodes cornuatus (southern paralysis tick) and Rhipicephalus australis (Australian cattle tick); and consideration of the place of Australia in the evolution of ticks with comments on four controversial ideas. Int J Parasitology. 2014;44(12):941 - 53.

9. Doherty RL, Carley JG, Murray MD, Main AJ, Jr., Kay BH, Domrow R. Isolation of arboviruses (Kemerovo group, Sakhalin group) from Ixodes uriae collected at Macquarie Island, Southern ocean. Am J Trop Med Hyg. 1975;24(3):521-6.

10. St George TD, Doherty RL, Carley JG, Filippich C, Brescia A, Casals J, et al. The isolation of arboviruses including a new flavivirus and a new Bunyavirus from Ixodes (Ceratixodes) uriae (Ixodoidea: Ixodidae) collected at Macquarie Island, Australia, 1975-1979. Am J Trop Med Hyg. 1985;34(2):406-12.

11. St George TD, Standfast HA, Doherty RL, Carley JG, Fillipich C, Brandsma J. The isolation of Saumarez Reef virus, a new flavivirus, from bird ticks Ornithodoros capensis and Ixodes eudyptidis in Australia. Aust J Exp Biol Med Sci. 1977;55(5):493-9.

12. Grard G, Moureau G, Charrel RN, Lemasson JJ, Gonzalez JP, Gallian P, et al. Genetic characterization of tick-borne flaviviruses: new insights into evolution, pathogenetic determinants and taxonomy. Virology. 2007;361(1):80-92.

13. Palacios G, Savji N, Travassos da Rosa A, Guzman H, Yu X, Desai A, et al. Characterization of the Uukuniemi virus group (Phlebovirus: Bunyaviridae): evidence for seven distinct species. J Virol. 2013;87(6):3187.

14. Huang B, Firth C, Watterson D, Allcock R, Colmant AMG, Hobson-Peters J, et al. Genetic characterization of archived bunyaviruses and their potential for emergence in Australia. Emerging Infect Dis. 2016;22(5):833-40. 
15. Major L, Linn ML, Slade RW, Schroder WA, Hyatt AD, Gardner J, et al. Ticks associated with Macquarie island penguins carry arboviruses from four genera. PLoS One. 2009;4(2):e4375.

16. St George TD, Cybinski DH, Main AJ, McKilligan N, Kemp DH. Isolation of a new arbovirus from the tick Argas robertsi from a cattle egret (Bubulcus ibis coromandus) colony in Australia. Aust J Biol Sci. 1984;37(3):85-9.

17. Gauci PJ, McAllister J, Mitchell IR, Cybinski D, St George T, Gubala AJ. Genomic characterisation of Vinegar Hill virus, an Australian nairovirus isolated in 1983 from Argas robertsi ticks collected from cattle egrets. Viruses. 2017;9(12):373.

18. Doherty RL, Kay BH, Carley JG, Filippich C. Isolation of virus strains related to kao shuan virus from Argas robertsi in northern territory, Australia. Search. 1976;7:484-6.

19. Humphery-Smith I, Cybinski DH, Byrnes KA, St George TD. Seroepidemiology of arboviruses among seabirds and island residents of the Great Barrier Reef and Coral Sea. Epidemiol Infect. 1991;107(2):435-40.

20. Harvey E, Rose K, Eden JS, Lo N, Abeyasuriya T, Shi M, et al. Extensive diversity of RNA viruses in Australian ticks. J Virol. 2018:e01358-18.

21. Chandra S, Harvey E, Emery D, Holmes EC, Šlapeta J. Unbiased Characterization of the Microbiome and Virome of Questing Ticks. Front Microbiol. 2021;12:627327-.

22. Vasilakis N, Tesh RB, Popov VL, Widen SG, Wood TG, Forrester NL, et al. Exploiting the Legacy of the Arbovirus Hunters. Viruses. 2019;11(5):471.

23. O'Brien CA, Hobson-Peters J, Yam AW, Colmant AM, McLean BJ, Prow NA, et al. Viral RNA intermediates as targets for detection and discovery of novel and emerging mosquito-borne viruses. PLoS Negl Trop Dis. 2015;9(3):e0003629.

24. Warrilow D, Huang B, Newton ND, Harrison JJ, Johnson KN, Chow WK, et al. The taxonomy of an Australian nodavirus isolated from mosquitoes. PLoS One. 2019;13(12):e0210029.

25. McLean BJ, Hobson-Peters J, Webb CE, Watterson D, Prow NA, Nguyen HD, et al. A novel insectspecific flavivirus replicates only in Aedes-derived cells and persists at high prevalence in wild Aedes vigilax populations in Sydney, Australia. Virology. 2015;486:272-83.

26. Harrison JJ, Warrilow D, McLean BJ, Watterson D, O'Brien CA, Colmant AM, et al. A new orbivirus isolated from mosquitoes in North-Western Australia shows antigenic and genetic similarity to Corriparta virus but does not replicate in vertebrate cells. Viruses. 2016;8(5):141.

27. O'Brien CA, Pegg CL, Nouwens AS, Bielefeldt-Ohmann H, Huang B, Warrilow D, et al. A unique relative of Rotifer birnavirus isolated from Australian mosquitoes. Viruses. 2020;12(9):1056. 
28. O'Brien CA, McLean BJ, Colmant AMG, Harrison JJ, Hall-Mendelin S, van den Hurk AF, et al. Discovery and characterisation of Castlerea virus, a new species of negevirus isolated in Australia. Evol Bioinform Online. 2017;13:1 - 14.

29. Colmant AMG, apos, Brien CA, Newton ND, Watterson D, Hardy J, et al. Novel monoclonal antibodies against Australian strains of negeviruses and insights into virus structure, replication and host -restriction. J Gen Virol. 2020:440-52.

30. Colmant AMG, Bielefeldt-Ohmann H, Hobson-Peters J, Suen WW, O'Brien CA, van den Hurk AF, et al. A newly discovered flavivirus in the yellow fever virus group displays restricted replication in vertebrates. J Gen Virol. 2016;97(5):1087-93.

31. Lawrie CH, Uzcátegui NY, Armesto M, Bell-Sakyi L, Gould EA. Susceptibility of mosquito and tick cell lines to infection with various flaviviruses. Med Vet Entomol. 2004;18(3):268-74.

32. Bell-Sakyi L, Kohl A, Bente DA, Fazakerley JK. Tick cell lines for study of Crimean-Congo hemorrhagic fever virus and other arboviruses. Vector Borne Zoonotic Dis. 2011;12(9):769-81.

33. Matsuno K, Kajihara M, Nakao R, Nao N, Mori-Kajihara A, Muramatsu M, et al. The unique phylogenetic position of a novel tick-borne phlebovirus ensures an Ixodid origin of the genus Phlebovirus. mSphere. 2018;3(3).

34. O'Brien CA, Hall-Mendelin S, Hobson-Peters J, Deliyannis G, Allen A, Lew-Tabor A, et al. Discovery of a novel iflavirus sequence in the eastern paralysis tick Ixodes holocyclus. Arch Virol. 2018;163(9).

35. Munderloh UG, Kurtti TJ. Formulation of medium for tick cell culture. Exp Appl Acarol. 1989;7(3):219-29.

36. Reed LJ, Muench H. A simple method of estimating fifty percent endpoints. Am J Epidemiol. 1938;27(3):493-7.

37. Bailey UM, Jamaluddin MF, Schulz BL. Analysis of congenital disorder of glycosylation-Id in a yeast model system shows diverse site-specific under-glycosylation of glycoproteins. J Proteome Res. 2012;11(11):5376-83.

38. Colmant AMG, Hall-Mendelin S, Ritchie SA, Bielefeldt-Ohmann H, Harrison JJ, Newton ND, et al. The recently identified flavivirus Bamaga virus is transmitted horizontally by Culex mosquitoes and interferes with West Nile virus replication in vitro and transmission in vivo. PLoS Negl Trop Dis. 2018;12(10):e0006886.

39. Madeira F, Park YM, Lee J, Buso N, Gur T, Madhusoodanan N, et al. The EMBL-EBI search and sequence analysis tools APIs in 2019. Nucleic Acids Res. 2019;47(W1):W636-W41. 
40. Gupta RaB, S. Prediction of glycosylation across the human proteome and the correlation to protein function. Pacific Symposium on Biocomputing 2002;7:310-22.

41. Finn RD, Clements J, Eddy SR. HMMER web server: interactive sequence similarity searching. Nucleic Acids Res. 2011;39(Web Server issue):W29-W37.

42. Duckert P, Brunak S, Blom N. Prediction of proprotein convertase cleavage sites. Protein engineering, design \& selection : PEDS. 2004;17(1):107-12.

43. Miller M, Pfeiffer, W, and Schwartz, T Creating the CIPRES Science Gateway for inference of large phylogenetic trees. Proceedings of the Gateway Computing Environments Workshop (GCE); 14/11/2010; New Orleans2010. p. 1-8.

44. Katoh K, Kuma K-I, Toh H, Miyata T. MAFFT version 5: improvement in accuracy of multiple sequence alignment. Nucleic Acids Res. 2005;33.

45. Darriba D, Taboada GL, Doallo R, Posada D. jModelTest 2: more models, new heuristics and parallel computing. Nat Meth. 2012;9(8):772-.

46. Rodriguez-Valle M, McAlister S, Moolhuijzen PM, Booth M, Agnew K, Ellenberger C, et al. Immunomic investigation of holocyclotoxins to produce the first protective anti-venom vaccine against the Australian paralysis tick, Ixodes holocyclus. Frontiers in Immunology. 2021;12(4091).

47. Kelley LA, Mezulis S, Yates CM, Wass MN, Sternberg MJE. The Phyre2 web portal for protein modeling, prediction and analysis. Nat Protoc. 2015;10:845.

48. Pettersen EF, Goddard TD, Huang CC, Couch GS, Greenblatt DM, Meng EC, et al. UCSF Chimera-a visualization system for exploratory research and analysis. Journal of computational chemistry. 2004;25(13):1605-12.

49. Ferron F, Li Z, Danek El, Luo D, Wong Y, Coutard B, et al. The hexamer structure of the Rift Valley fever virus nucleoprotein suggests a mechanism for its assembly into ribonucleoprotein complexes. PLoS Pathog. 2011;7(5):e1002030.

50. Sun Y, Li J, Gao GF, Tien P, Liu W. Bunyavirales ribonucleoproteins: the viral replication and transcription machinery. Crit Rev Microbiol. 2018;44(5):522-40.

51. Frost MJ, Zhang J, Edmonds JH, Prow NA, Gu X, Davis R, et al. Characterization of virulent West Nile virus Kunjin strain, Australia, 2011. Emerging Infect Dis. 2012;18(5):792-800.

52. Schönborn J, Oberstrass J, Breyel E, Tittgen J, Schumacher J, Lukacs N. Monoclonal antibodies to double-stranded RNA as probes of RNA structure in crude nucleic acid extracts. Nucleic Acids Res. 1991;19(11):2993-3000. 
53. Ong C, Rodriguez-Valle M, Moolhuijzen P, Barrero R, Hunter A, Szabo T, et al. Exploring the transcriptomic data of the Australian paralysis tick, Ixodes holocyclus. GSTF J Vet Sci. 2016;3(1):1-10.

54. Wille M, Harvey E, Shi M, Gonzalez-Acuña D, Holmes EC, Hurt AC. Sustained RNA virome diversity in Antarctic penguins and their ticks. Isme j. 2020;14(7):1768-82.

55. Pettersson JHO, Ellström P, Ling J, Nilsson I, Bergström S, González-Acuña D, et al. Circumpolar diversification of the Ixodes uriae tick virome. PLoS Pathog. 2020;16(8):e1008759.

56. Olal D, Dick A, Woods VL, Jr., Liu T, Li S, Devignot S, et al. Structural insights into RNA encapsidation and helical assembly of the Toscana virus nucleoprotein. Nucleic Acids Res. 2014;42(9):6025-37.

57. Wang J, Selleck P, Yu M, Ha W, Rootes C, Gales R, et al. Novel phlebovirus with zoonotic potential isolated from ticks, Australia. Emerg Infect Dis. 2014;20(6):1040-3.

58. Arnal A, Gómez-Díaz E, Cerdà-Cuéllar M, Lecollinet S, Pearce-Duvet J, Busquets N, et al. Circulation of a Meaban-like virus in Yellow-legged gulls and seabird ticks in the Western Mediterranean Basin. PLoS One. 2014;9(3):e89601.

59. Chastel C, Main AJ, Guiguen C, le Lay G, Quillien MC, Monnat JY, et al. The isolation of Meaban virus, a new flavivirus from the seabird tick Ornithodoros (Alectorobius) maritimus in France. Arch Virol. 1985;83(3):129-40.

60. Bell-Sakyi L, Růzek D, Gould EA. Cell lines from the soft tick Ornithodoros moubata. Exp Appl Acarol. 2009;49(3):209-19.

61. Garcia S, Billecocq A, Crance J-M, Munderloh U, Garin D, Bouloy M. Nairovirus RNA sequences expressed by a Semliki Forest virus replicon induce RNA interference in tick cells. J Virol. 2005;79(14):8942.

62. Offerdahl DK, Dorward DW, Hansen BT, Bloom ME. A three-dimensional comparison of tick-borne flavivirus infection in mammalian and tick cell lines. PloS one. 2012;7(10):e47912-e.

63. Yau W-L, Nguyen-Dinh V, Larsson E, Lindqvist R, Överby AK, Lundmark R. Model System for the Formation of Tick-Borne Encephalitis Virus Replication Compartments without Viral RNA Replication. J Virol. 2019;93(18):e00292-19.

64. Miorin L, Romero-Brey I, Maiuri P, Hoppe S, Krijnse-Locker J, Bartenschlager R, et al. ThreeDimensional Architecture of Tick-Borne Encephalitis Virus Replication Sites and Trafficking of the Replicated RNA. J Virol. 2013;87(11):6469.

65. Gillespie LK, Hoenen A, Morgan G, Mackenzie JM. The Endoplasmic Reticulum Provides the Membrane Platform for Biogenesis of the Flavivirus Replication Complex. J Virol. 2010;84(20):10438. 
66. Arakawa M, Morita E. Flavivirus Replication Organelle Biogenesis in the Endoplasmic Reticulum: Comparison with Other Single-Stranded Positive-Sense RNA Viruses. Int J Mol Sci. 2019;20(9):2336.

67. Belaganahalli MN, Maan S, Maan NS, Brownlie J, Tesh R, Attoui H, et al. Genetic characterization of the tick-borne orbiviruses. Viruses. 2015;7(5):2185-209.

68. Attoui H, Mertens PPC, Becnel J, Belaganahalli S, Bergoin M, Brussaard CP, et al. Family Reoviridae. In: King AMQ, Adams MJ, Carstens EB, Lefkowitz EJ, editors. Virus Taxonomy Classification and Nomenclature of Viruses, Ninth Report of the International Committee on Taxonomy of Viruses. San Diego, CA, USA: Elsevier; 2011. p. 541 - 637.

69. Tokarz R, Williams SH, Sameroff S, Sanchez Leon M, Jain K, Lipkin WI. Virome analysis of Amblyomma americanum, Dermacentor variabilis, and Ixodes scapularis ticks reveals novel highly divergent vertebrate and invertebrate viruses. J Virol. 2014;88(19):11480.

70. Khromykh AA, Kenney MT, Westaway EG. trans-Complementation of flavivirus RNA polymerase gene NS5 by using Kunjin virus replicon-expressing BHK cells. J Virol. 1998;72(9):7270-9.

71. Gentry MK, Henchal EA, McCown JM, Brandt WE, Dalrymple JM. Identification of distinct antigenic determinants on dengue-2 virus using monoclonal antibodies. Am J Trop Med Hyg. 1982;31(3 Pt 1):54855 .

72. Hall RA, Kay BH, Burgess GW, Clancy P, Fanning ID. Epitope analysis of the envelope and nonstructural glycoproteins of Murray Valley Encephalitis Virus. J Gen Virol. 1990;71(12):2923-30.

73. Thibodeaux BA, Roehrig JT. Development of a human-murine chimeric immunoglobulin M antibody for use in the serological detection of human flavivirus antibodies. Clinical and Vaccine Immunology. 2009;16(5):679.

74. Hall RA, Broom AK, Hartnett AC, Howard MJ, Mackenzie JS. Immunodominant epitopes on the NS1 protein of MVE and KUN viruses serve as targets for a blocking ELISA to detect virus-specific antibodies in sentinel animal serum. J Virol Meth. 1995;51(2):201-10.

75. Macdonald J, Poidinger M, Mackenzie JS, Russell RC, Doggett S, Broom AK, et al. Molecular phylogeny of Edge Hill virus supports its position in the yellow Fever virus group and identifies a new genetic variant. Evol Bioinform Online. 2010;6:91-6.

76. Piyasena TBH, Newton ND, Hobson-Peters J, Vet LJ, Setoh YX, Bielefeldt-Ohmann H, et al. Chimeric viruses of the insect-specific flavivirus Palm Creek with structural proteins of vertebrate-infecting flaviviruses identify barriers to replication of insect-specific flaviviruses in vertebrate cells. J Gen Virol. 2019;100(11):1580-6.

77. Belhouchet M, Mohd Jaafar F, Tesh R, Grimes J, Maan S, Mertens PPC, et al. Complete sequence of Great Island virus and comparison with the T2 and outer-capsid proteins of Kemerovo, Lipovnik and 
Tribec viruses (genus Orbivirus, family Reoviridae). J Gen Virol. 2010;91(12):2985-93.

78. Dilcher M, Weidmann M. Confusions in orbivirus protein classification. Virol J. 2012;9:166 - 22.

\section{Figures}

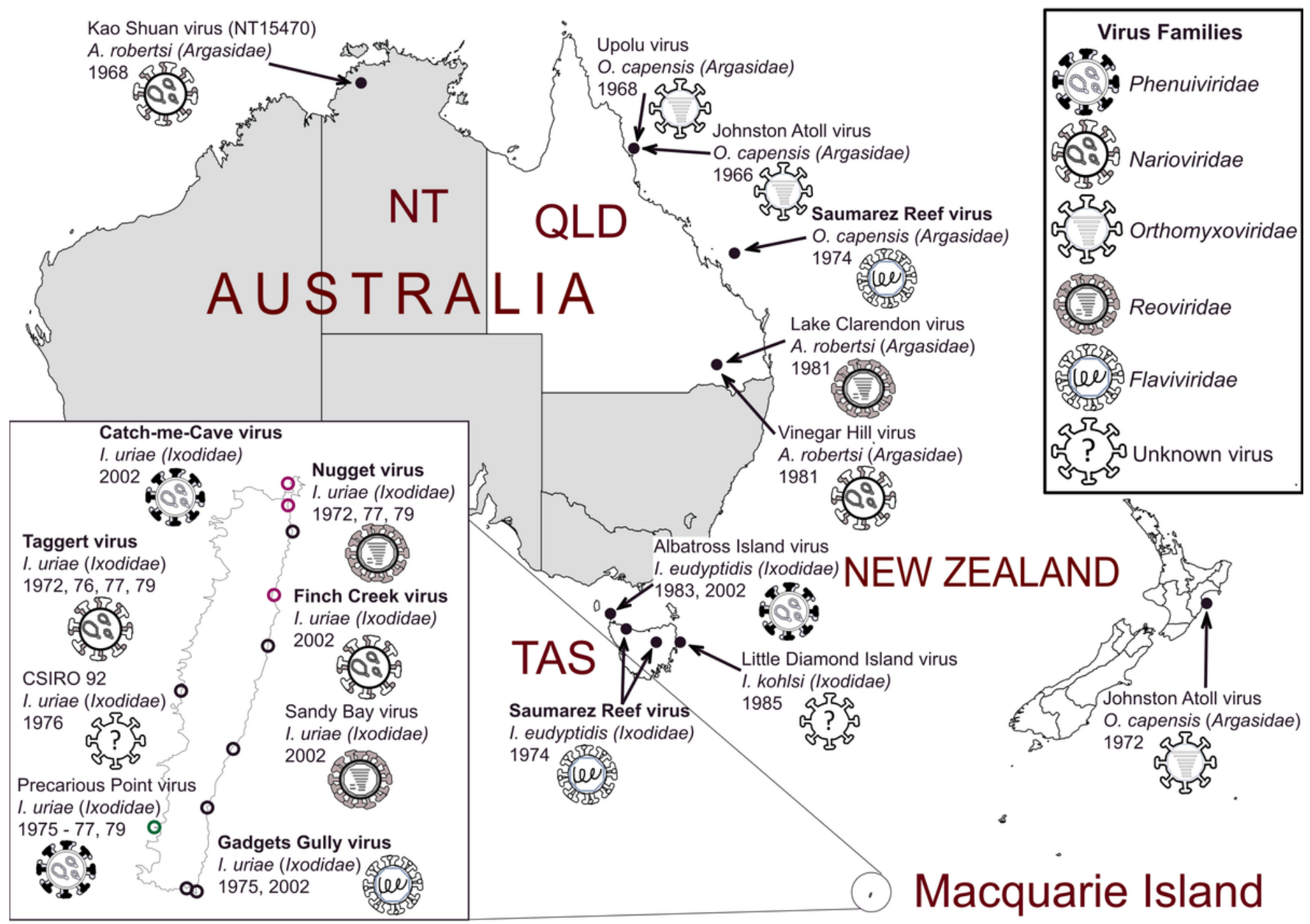

Figure 1

Schematic of tick viruses isolated in the Australia and New Zealand region. The tick species (family) of isolate and year of collection is indicated beneath the name of each virus. The viral family of each isolate is indicated by icons defined in the legend on the right-hand side of the figure. Bold text indicates viruses used in this study. Inset, summary of viruses isolated on Macquarie Island. Circled regions indicate sites where tick collections yielded virus isolates. Black circles, collection sites accessed between 1972 and 1979. Magenta circles, collection sites accessed in 2002. Green circle, Precarious Point where tick collections occurred both in the 1970s and 2002. Tick genus names: A., Argas; I., Ixodes; O., Ornithodoros. 

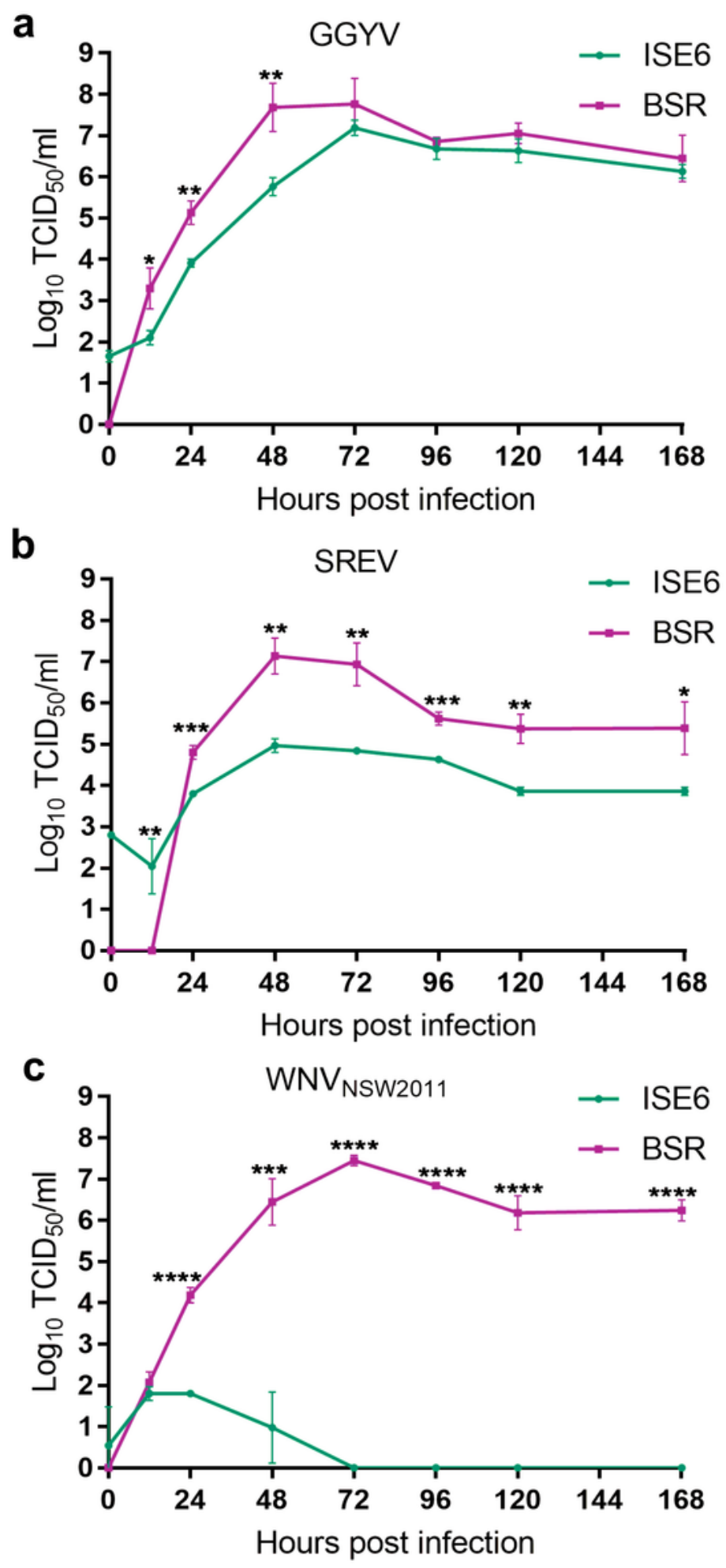

Figure 2

In vitro growth kinetics of tick-borne flaviviruses (a) GGYV and (b) SREV and (c) mosquito-borne flavivirus WNVKUN in vertebrate (BSR) and tick (ISE6) cells. Viral titres in supernatants from three replicate wells were determined by TCID50 method after titration on BSR cells. Statistical significance was determined at each time point by $t$ tests. *, $p<0.0332 ;{ }^{* *}, p<0.0021$; ${ }^{\star \star *}, p<0.0002 ;{ }^{* \star \star *}, p<0.0001$. 


\section{GGYV}

흥

Merge

5.93
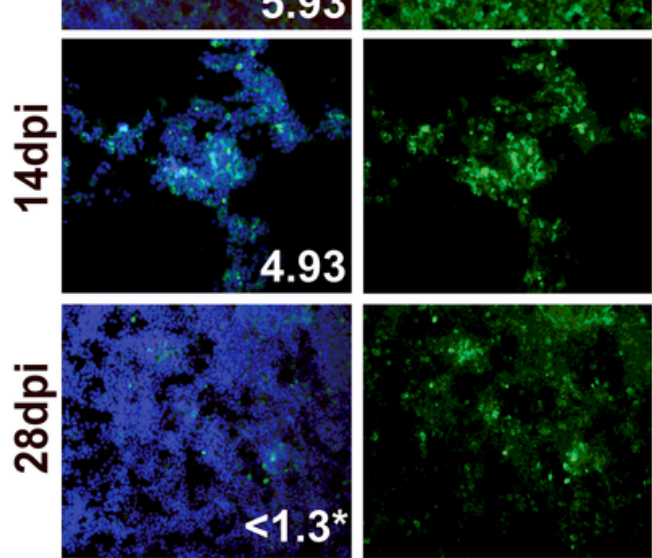

Mock
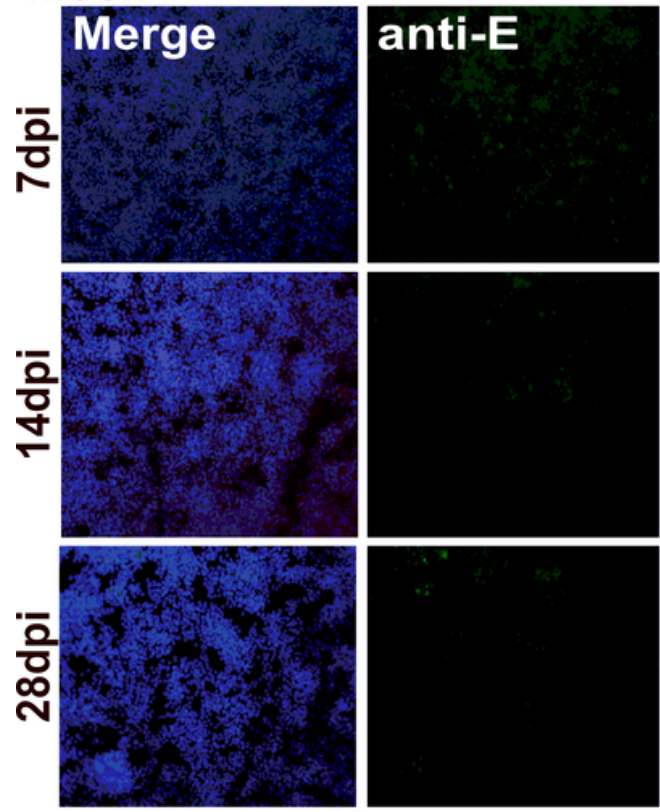

SREV
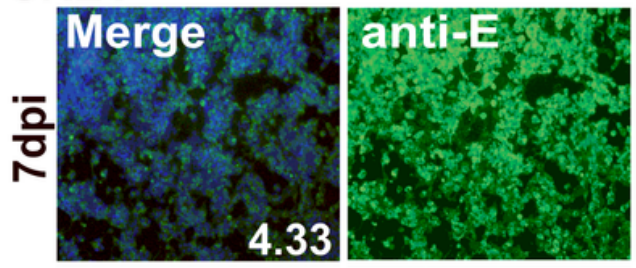

anti-dsRNA
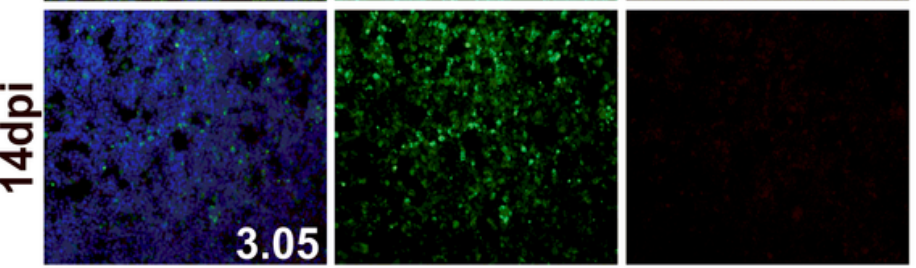

훙

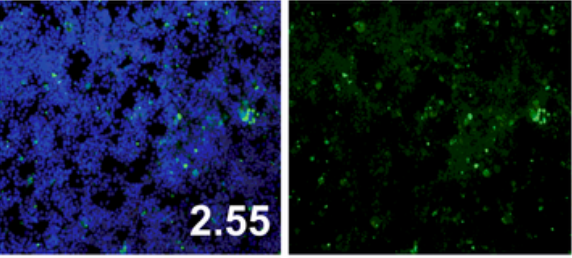

Antibody control
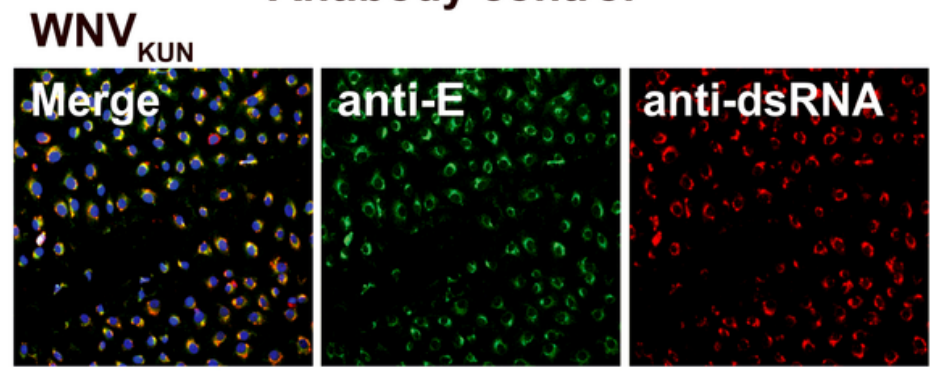

\section{Mock}
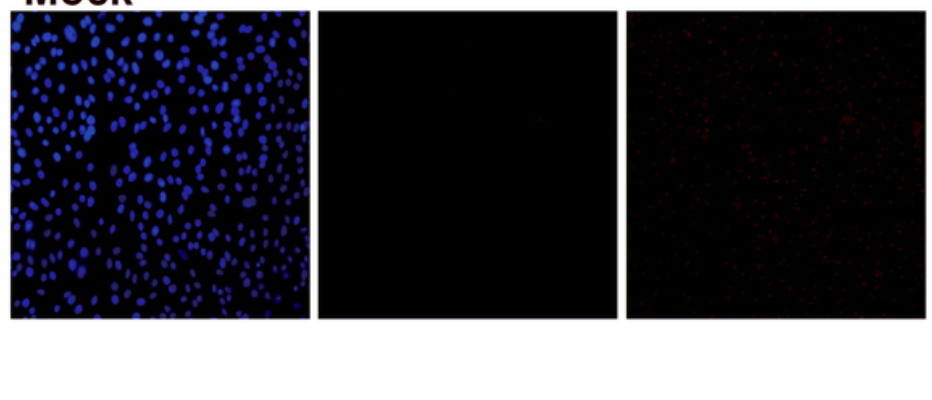

Figure 3

Immunofluorescence assay (IFA) on 100\% acetone-fixed ISE6 cells infected with GGYV and SREV at 7, 14, and 28 days post-infection (dpi). Immunofluorescent labelling with anti-E mAb 4G2 (green), anti-dsRNA MAVRIC (red) and Hoechst nuclear stain (blue). Mock controls, uninfected cells inoculated with culture medium only. WNVKUN-infected Vero cells were used as assay controls. The log value of average virus titres (TCID50 units $/ \mathrm{mL}$ ) recovered from supernatant harvested at each time point is indicated in white text at the bottom right corner of each merged panel. * indicates titre below the limit of detection $(<101.3 / \mathrm{mL})$. Images taken at $20 \times$ magnification with an EPI fluorescence microscope. 

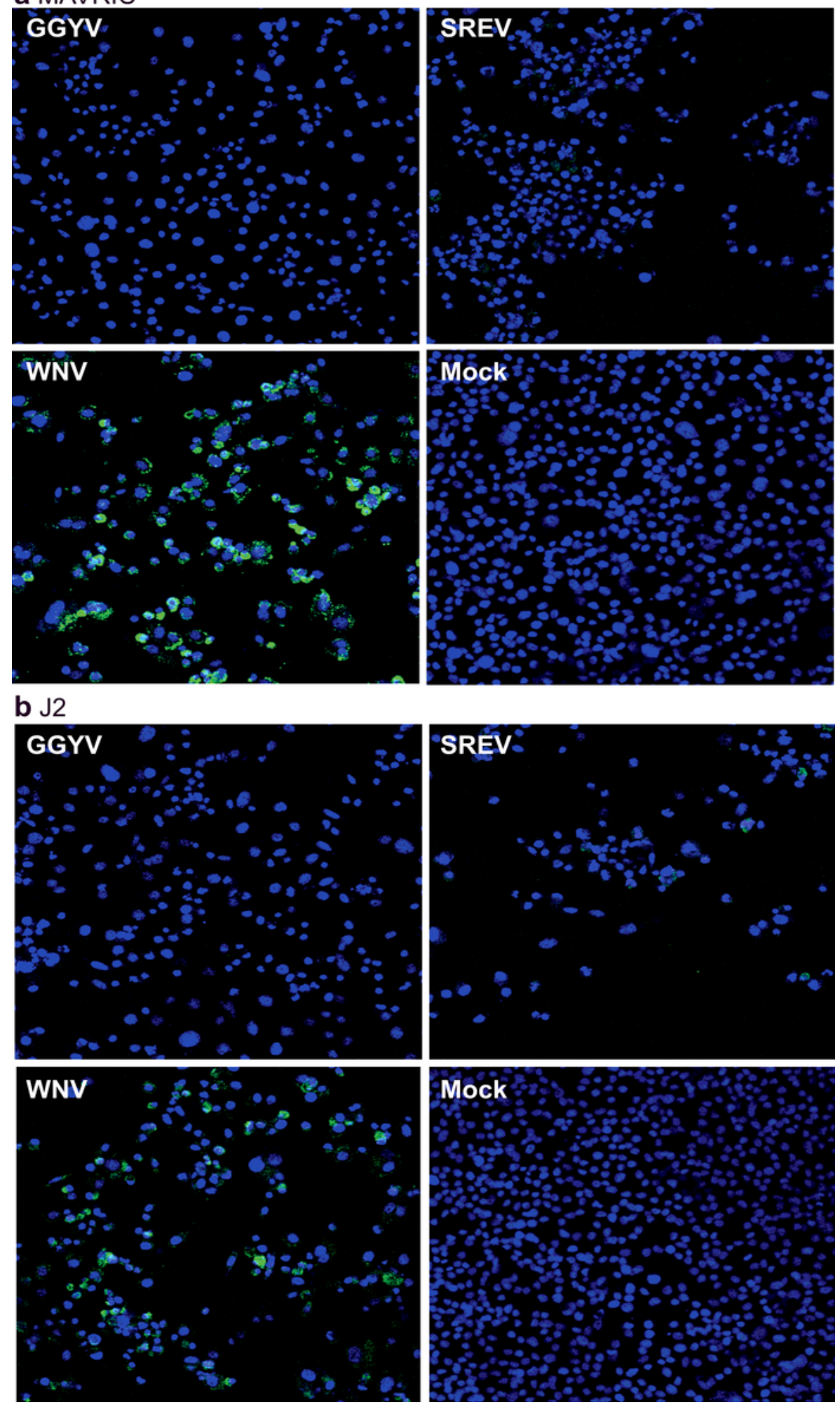

\section{Figure 4}

IFA analysis of tick- and mosquito-borne flavivirus-infected cells using anti-dsRNA mAbs (a) MAVRIC and (b) J2. Representative images of BSR cells infected with GGYV, SREV, WNVKUN or mock-infected. At 5 dpi cells werefixed with $4 \%$ formaldehyde and permeabilised with $0.5 \%$ Triton X-114 . Blue, nuclei; green, dsRNA. Images taken at $20 \times$ magnification. 

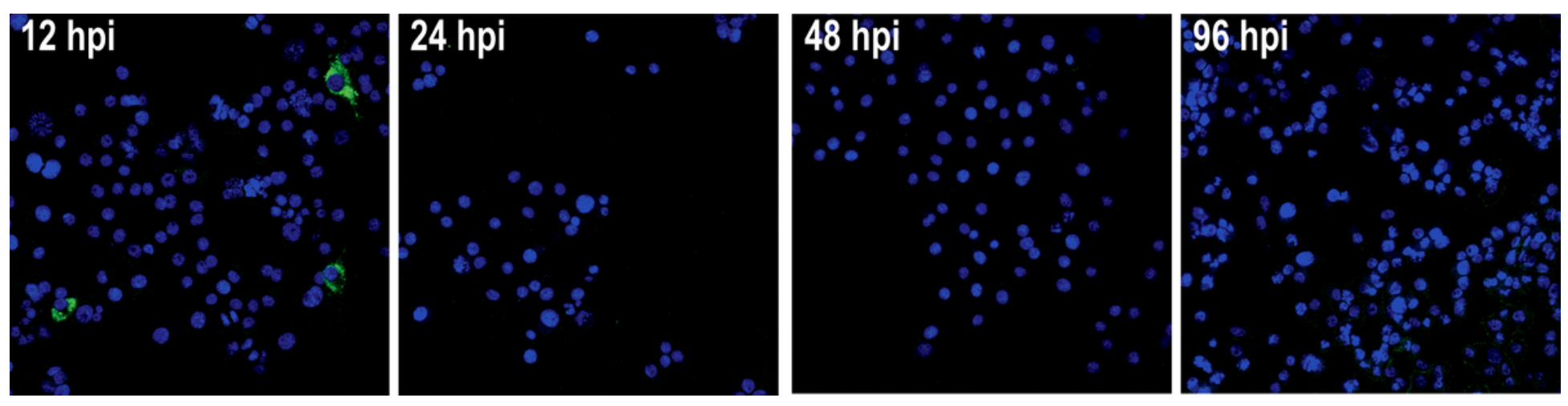

Figure 5

GGYV-infected BSR cells fixed with $100 \%$ acetone and immunolabelled for dsRNA using mAb J2 at early timepoints post-infection. Images taken at $20 \times$ magnification. Blue, nuclei; green, dsRNA.

a

L protein

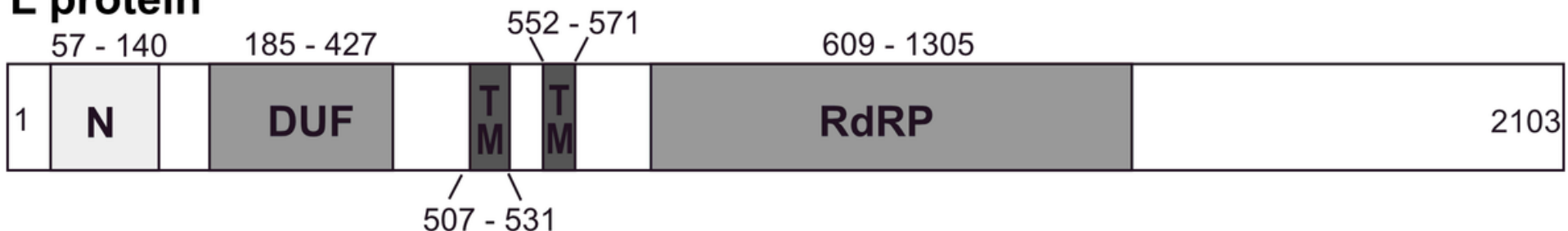

\section{Glycoprotein precursor}

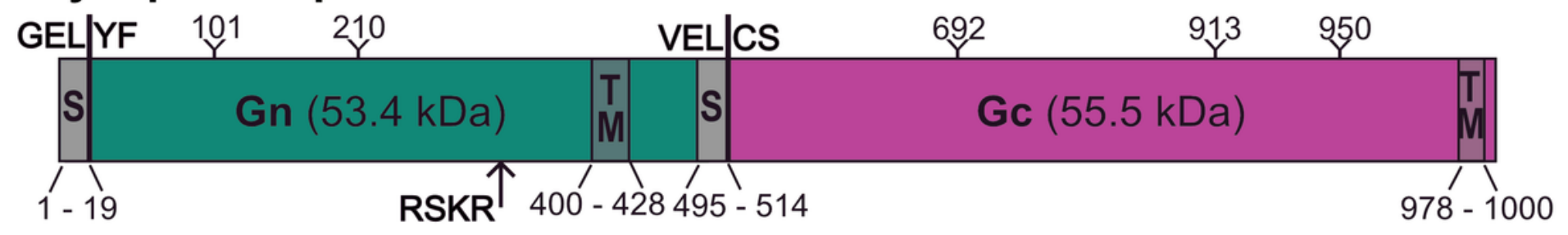

b

\begin{tabular}{|ccccccc|}
\hline Segment & $\begin{array}{c}\text { Nucleotide accession } \\
\text { no. }\end{array}$ & Gene & $\begin{array}{c}\text { Sequence } \\
\text { length (nt) }\end{array}$ & $\begin{array}{c}\text { Protein } \\
\text { length } \\
\text { (aa) }\end{array}$ & $\begin{array}{c}\text { PPV } \\
\text { segment } \\
\text { length (nt) }\end{array}$ & $\begin{array}{c}\text { \% Pairwise } \\
\text { identity with } \\
\text { PPV (nt/aa) }\end{array}$ \\
\hline $\mathrm{L}$ & OK493375 & RdRP & 6466 & 2103 & 6466 & $94.7 / 99.8$ \\
\hline $\mathrm{M}$ & OK493376 & Glycoprotein & 3271 & 1009 & 3285 & $94.4 / 99.3$ \\
\hline $\mathrm{S}$ & EU274384 a & Nucleocapsid & 1331 & 159 & 1785 & $95.7 / 100$ \\
& NS-S & 236 & $95.7 / 96.2$ \\
\hline
\end{tabular}

${ }^{a}$ CMCV S segment sequence not generated in this study, corresponding accession numbers for amino acid sequences: nucleocapsid protein (ABX83572) and Non-structural protein encoded on S segment (NS-S) (ABX83571).

${ }^{b}$ PPV, Precarious point virus, nucleotide sequences (HM566179 to HM566181), amino acid sequences (AEL29677 to AEL29680).

Figure 6

In vitro replication of NUGV in vertebrate and tick cell lines. (a) Growth kinetics analysis of NUGV in ISE6 and BSR cells. Viral titres in supernatants from three replicate wells were determined by TCID50 method 
after titration on BSR cells. Statistical significance was determined using t tests for each time point. *, $\mathrm{p}$ $<0.0332$; $* \star, p<0.0021$; ***, $p<0.0002$; $* \star \star *, p<0.0001$. (b) Detection of dsRNA in NUGV-infected BSRs at various time points post-infection. (c) Detection of dsRNA in NUGV-infected ISE6 cells at various time points post-infection. Blue, Hoechst nuclear stain; green, anti-dsRNA immunolabelling by MAVRIC. Images taken at $40 \times$ magnification.

a

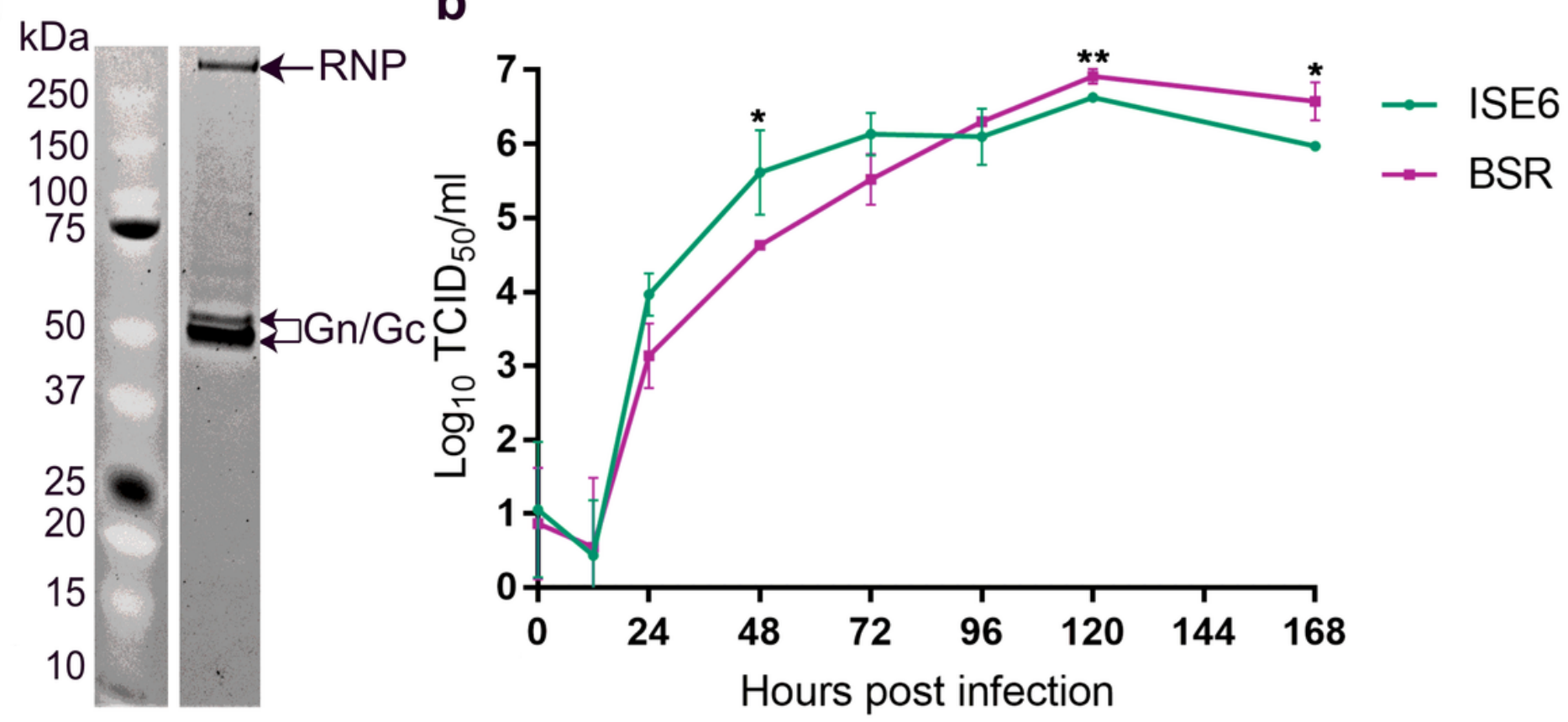

Figure 7

Phylogenetic relationship of NUGV and members of the genus Orbivirus and NUGV. Phylogenetic trees were constructed from the aligned nucleotide coding sequences of (a) VP1 (polymerase), and (b) VP5 (OC2) for tick-borne orbiviruses only. Phylogenetic analysis of VP1 sequences was performed in MEGA7 using the $\mathrm{JC}+\mathrm{G}=4$ model. Bold branches denote members of the tick-borne orbivirus group. VP5 phylogenetic analysis was performed in MEGA7 using the $\mathrm{JC}+\mathrm{I}$ model and bold branches denote the Great Island virus species complex. The percentage of trees in which the associated taxa clustered together is shown next to the branches. 


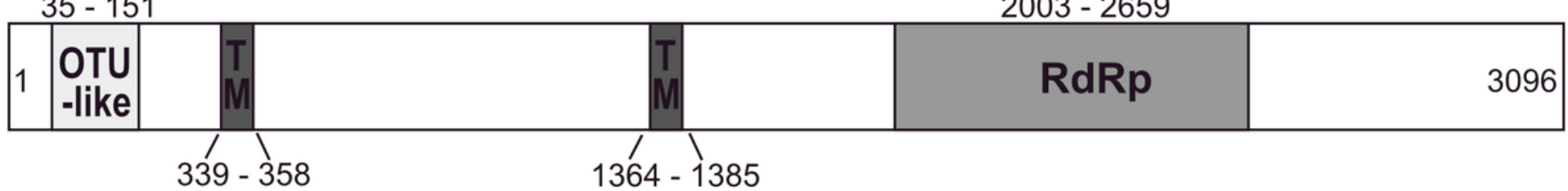

Glycoprotein precursor

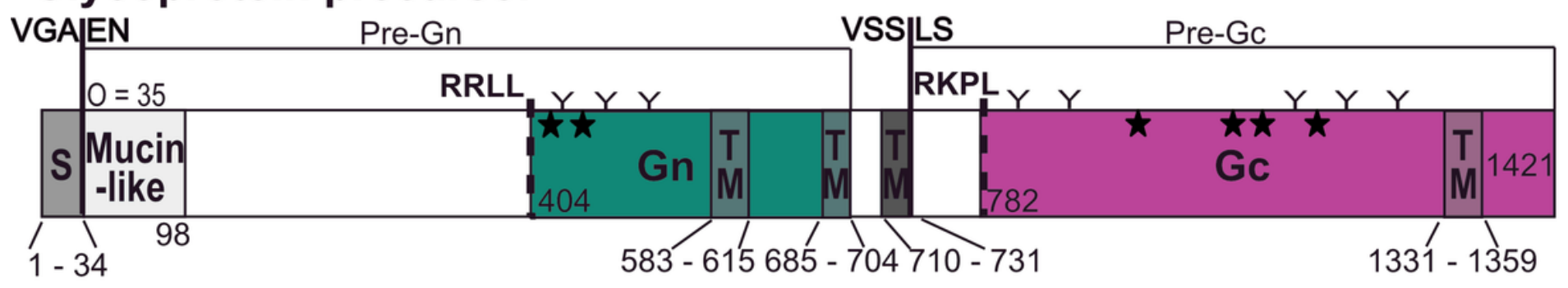

Nuclecapsid protein

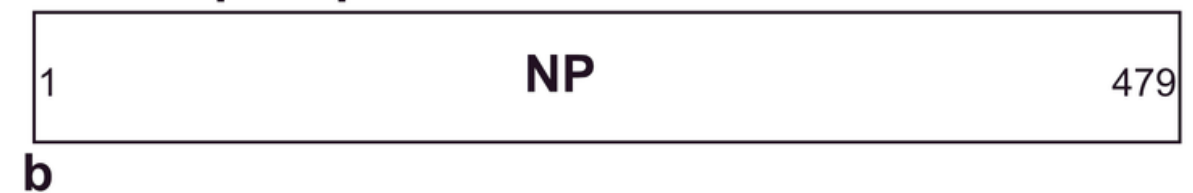

\begin{tabular}{ccccccc}
\hline Segment a & Gene & $\begin{array}{c}\text { Sequence } \\
\text { length (nt) }\end{array}$ & $\begin{array}{c}\text { Protein } \\
\text { length (aa) }\end{array}$ & $\begin{array}{c}\text { \% Pairwise identity } \\
\text { with TAGV MI14850 } \\
\text { (nt/aa) }\end{array}$ & $\begin{array}{c}\text { \% Pairwise } \\
\text { TAGV Paradise } \\
\text { Bay (nt/aa) }\end{array}$ & $\begin{array}{c}\text { \% Pairwise } \\
\text { identity with } \\
\text { FCV (nt/aa) }\end{array}$ \\
\hline L & RdRp & 11849 & 3906 & $99.4 / 99.9$ & $81.4 / 94.08$ & $97.7 / 99.2$ \\
M & Glycoprotein & 4545 & 1421 & $97.8 / 99.6$ & $73.8 / 79.7$ & - \\
S & Nucleocapsid & 1603 & 479 & $99.6 / 100$ & $79.8 / 89.4$ & - \\
\hline
\end{tabular}

a Accession numbers for FCV nucleotide sequences generated in this study L segment (OK493377), $M$ segment (OK493378), S segment (OK493379)

b TAGV, Taggert virus prototype isolate MI14850 nucleotide sequences (KU925491 to KU925493), amino acid sequences (AMR73395 to AMR73397)

c TAGV, 2017 isolate from Paradise Bay, Antarctica. Nucleotide sequences (MT025170 to MT025172), amino acid sequences (QIS88061 to QIS88063)

${ }^{d}$ FCV original L segment sequence. Nucleotide (EU267169) and amino acid (ABX80519)

Figure 8

Sequence analysis of CMCV. (a) Annotation of CMCV L protein and glycoprotein precursor. Numbers indicate relevant amino acid positions. Green: Gn protein. Magenta: Gc. Predicted signal peptidase cleavage sites preceding Gn (GEL-YF) and Gc (VEL-CS) are indicated by solid lines. An arrow indicates the position of a predicted furin cleavage site in the Gn protein. DUF, domain of unknown function (pfam: DUF3770); RdRp, RNA-dependent RNA polymerase; TM, transmembrane domain; S, signal peptide; Y, predicted N-glycan. (b) Summary of CMCV sequence data for the $L$ and $M$ segment generated in this study and similarity to Precarious point virus. CMCV S segment sequence was published in (15) 


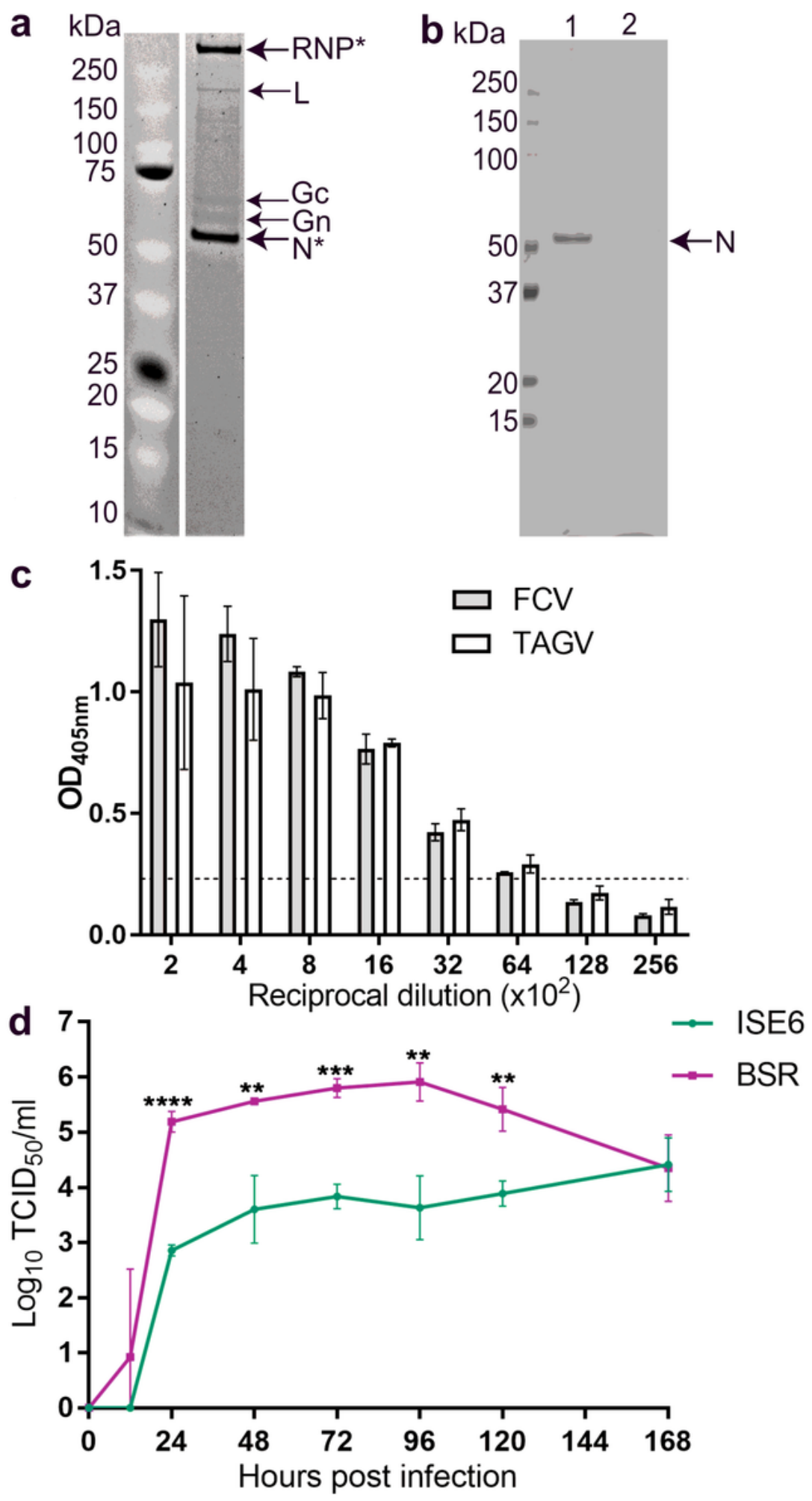

\section{Figure 9}

In vitro analysis of tick-borne phlebovirus CMCV. (a) SDS-PAGE analysis of purified CMCV. (b) Growth kinetics of CMCV in vertebrate (BSR, baby hamster kidney) and tick (ISE6, Ixodes scapularis) cells. Viral titres in supernatants from three replicate wells were determined by TCID50 method after titration on BSR cells. Statistical significance was determined using $t$ tests for each time point. ${ }^{*}, p<0.0332 ; * \star, p<0.0021$; $\star \star \star, ~ p<0.0002 ; * \star \star \star, p<0.0001$. 


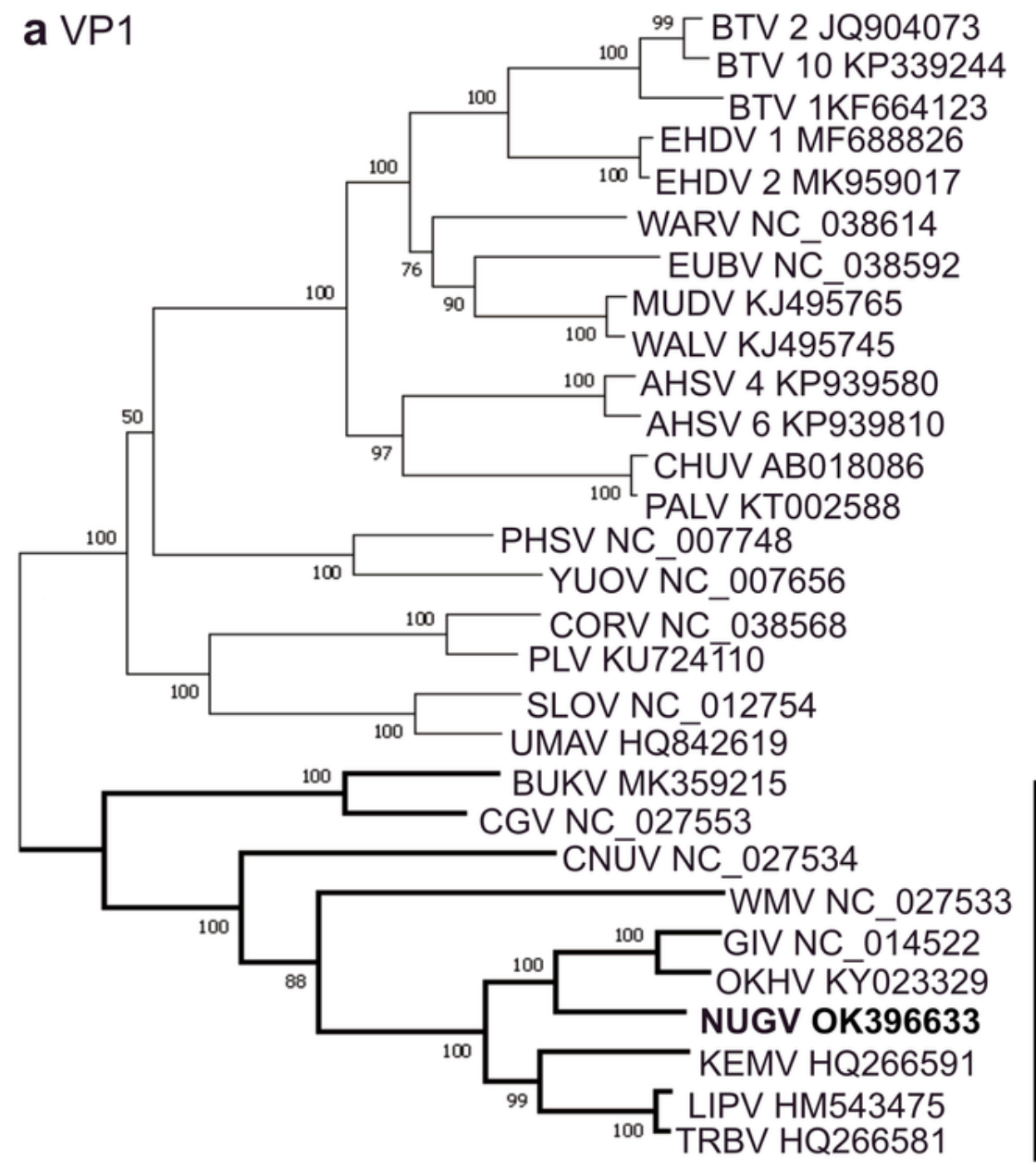

\section{Tick-borne orbiviruses}

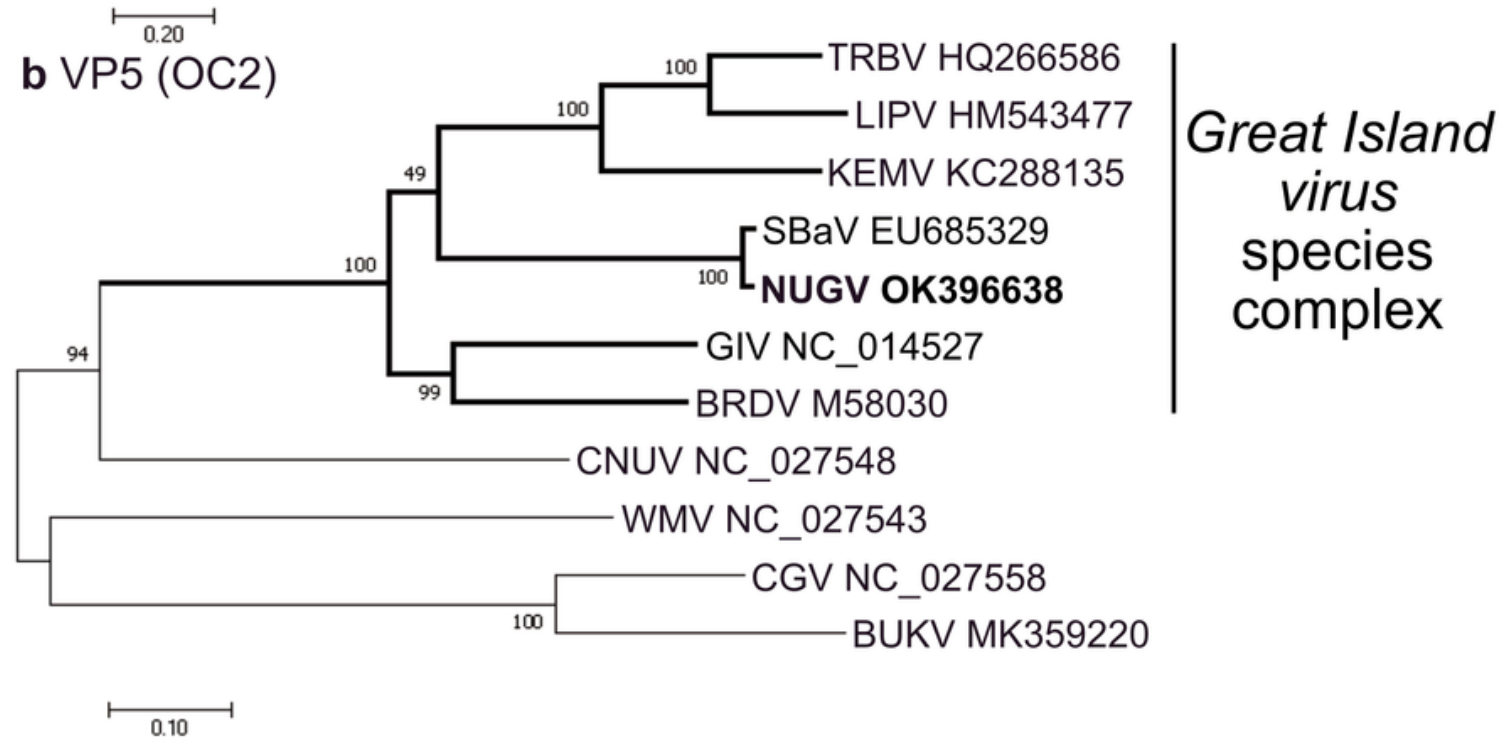

Figure 10

Finch creek virus sequencing. (a) Sequence annotation of FCV L, M and S polypeptides based on predictions of protein domains and cleavage sites. Numbers on the figure indicate relevant amino acid positions. OTU-like, ovarian tumor family-like domain. RdRp, RNA dependent RNA polymerase domain. Transmembrane domains (TM) are indicated by dark grey boxes. S, signal peptide. Signal peptidase cleavage sites for the Pre-Gn (VGA34EN) and Pre-Gc (VSS733LS) proteins are indicated by cleavage site 
sequence and bold solid line. Subtilisin kexin isozyme-1 (SKI-1) cleavage sites (RRLL, RKPL) are indicated by dashed lines. The number of predicted O-linked glycosylation sites in the mucin-like domain is indicated above the domain ( $\mathrm{O}=$ number of sites). Green: $\mathrm{Gn}$ protein. Magenta: Gc protein. Predicted Nand O-linked glycans in the $\mathrm{Gn}$ and $\mathrm{Gc}$ proteins are indicated by $\mathrm{Y}$ or *, respectively. (b) Summary of sequence data generated for FCV and comparison to available sequences for prototype TAGV strain MI14850 (Macquarie Island, 1972), TAGV Paradise Bay variant (Antarctica, 2017) and original FCV L protein sequence reported in (15).

\section{Supplementary Files}

This is a list of supplementary files associated with this preprint. Click to download.

- AdditionalFile1.pdf

- AdditionalFile2.xlsx

- GraphicalabstractPARV.tiff 